Prace Komisji Geografii Komunikacji PTG Transport Geography Papers of Pol

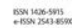

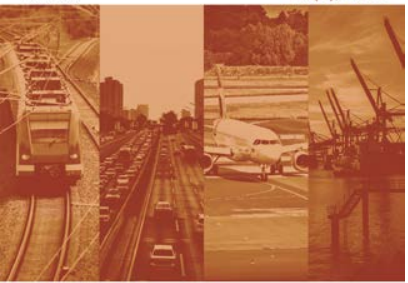

\section{Prace Komisji Geografii Komunikacji PTG}

$2019,22(4), 75-94$

DOI 10.4467/2543859XPKG.19.022.11543

Otrzymano (Received): 26.08.2019

Otrzymano poprawioną wersję (Received in revised form): 20.11.2019

Zaakceptowano (Accepted): 20.11.2019

Opublikowano (Published): 31.12.2019

\title{
DOJAZDY DO PRACY W AGLOMERACJI POZNAŃSKIEJ I WOJEWÓDZTWIE WIELKOPOLSKIM W 2016 ROKU
}

\section{Commuting in the agglomeration of Poznań and wielkopolskie voivodeship in 2016}

\author{
Radosław Bul \\ Instytut Geografii Społeczno-Ekonomicznej i Gospodarki Przestrzennej, Uniwersytet im. A. Mickiewicza w Poznaniu, Krygowskiego 10, 61-680 Poznań \\ e-mail: bul@amu.edu.pl
}

\section{Cytacja:}

Bul R., 2019, Dojazdy do pracy w aglomeracji poznańskiej i województwie wielkopolskim w 2016 roku, Prace Komisji Geografii Komunikacji PTG, 22(4), 75-94.

\begin{abstract}
Streszczenie: Celem opracowania jest identyfikacja skali i kierunków dojazdów do pracy na obszarze aglomeracji poznańskiej i województwa wielkopolskiego. Z uwagi na charakter przemieszczeń, szczegółowej analizie poddano dojazdy, których celem było miasto i jego aglomeracja. Dane dla 2016 r., opublikowane przez GUS w 2019 r., w tym macierz przepływów, pozwoliły na wskazanie jednostek, których powiązania funkcjonalne z Poznaniem są najsilniejsze. Uwzględniono ponadto ośrodki zlokalizowane w powiecie poznańskim przyjmujące najwięcej osób dojeżdżających. Celem opracowania było także wskazanie głównych ośrodków wyjazdów pracowniczych. Na tej podstawie możliwe stało się zdefiniowanie rozmieszczenia i wielkości lokalnych rynków pracy w ramach regionu.
\end{abstract}

Słowa kluczowe: dojazdy do pracy, aglomeracja poznańska, województwo wielkopolskie, migracje pracownicze

Abstract: The aim of the paper is to identify the scale and directions of commuting flows in the agglomeration of Poznań and wielkopolskie voivodeship. The article is based on the data of commuting flows in 2016 published by Polish Central Statistical Office in 2019. This information allowed to recognize the scale and direction of daily migrations to Poznan and identify several municipalities which have the strongest functional relationships with the core city. Another objective of the paper is to define a role of municipalities in the structure of commuting within Poznan agglomeration and the whole region. The analysis of the matrix of flows allowed to specify an extent and volume of local labor markets too.

Keywords: commuting, wielkopolskie voivodeship, agglomeration of Poznań, migrations 


\section{Wprowadzenie}

Dojazdy do pracy stanowią od dawna interesujący obszar badań geograficznych, z uwagi na złożony charakter przyczyn generujących zjawisko oraz jego zróżnicowanie przestrzenne. Pierwsze analizy skali i kierunków dojazdów prowadzone były pod koniec XIX w. (Szwajcaria, Niemcy), a na początku XX w. już większość urzędów statystycznych państw zachodnioeuropejskich zbierała dane o przemieszczeniach pracowniczych. Bardzo szybko okazało się, że większa skala i kierunki przepływów cechuje jednostki rozwinięte pod względem gospodarczym o dobrej dostępności transportowej, tj. wielkie metropolie, aglomeracje i zespoły miejskie, które stanowią najważniejsze bieguny wzrostu społeczno-gospodarczego.

Głównymi przyczynami rosnącej skali przemieszczeń pracowniczych w aglomeracjach, która ma swoje przełożenie na ogólny poziom mobilności na danym obszarze, są przede wszystkim: rozwój środków transportu i układów transportowych, zróżnicowanie przestrzenne poszczególnych funkcji występujących pomiędzy centrum jednostki a obszarami peryferyjnymi, dynamiczny wzrost liczby ludności gmin otaczających miasta oraz nierównowaga na regionalnym rynku pracy i zmiany w nim zachodzące. Szczególnie interesującym pod względem przestrzennym zjawiskiem są codzienne dojazdy do pracy, które zalicza się najczęściej do tzw. migracji lub przemieszczeń „wahadłowych” (Jagielski, 1974). Z uwagi na dużą częstotliwość, cykliczność i zasięg przestrzenny, dobowe przemieszczenia pracownicze generują wiele skutków o charakterze ekonomicznym, przestrzennym czy społecznym.

Dojazdy do pracy są niewątpliwie jedną z głównych miar przestrzenno-funkcjonalnych powiązań jednostek terytorialnych, stąd też bardzo często stanowią one ważne kryterium delimitacji obszarów funkcjonalnych miast. Jak podkreśla P. Korcelli (1976), zasięg codziennych potoków dojazdów do pracy stanowi cechę diagnostyczną, świadczącą o występowaniu na danym obszarze szerszego wachlarza związków, odzwierciedlających przestrzenną strukturę powiązań na rynku pracy w sektorze usług publicznych i komercyjnych. Z tego też względu przemieszczenia związane z wykonywaniem obowiązków zawodowych stanowią jedno z najważniejszych (a w niektórych przypadkach jedyne) kryterium delimitacji tego typu jednostek, np. w Stanach Zjednoczonych podstawowymi kryteriami delimitacji Standard Metropolian Statistical Area są dojazdy do pracy i odsetek zatrudnionych poza rolnictwem (Kaczmarek, Mikuła, 2007), w Wielkiej Brytanii Standard Metropolitan Labour Areas wyznacza się wy- łącznie na podstawie dojazdów do pracy (Pacione, 2001).

Zważywszy na postępujące zmiany przestrzenne zachodzące w dużych zespołach miejskich na terenie kraju (rozlewanie się zabudowy, redystrybucja ludności, redystrybucja podmiotów gospodarczych - tzw. suburbanizacja gospodarcza), informacje o dojazdach do pracy są niezwykle istotnym narzędziem z punktu widzenia zarządzania i planowania tych obszarów. Pozwalają one także na uchwycenie trendów rozwoju największych zespołów miejskich. Badania skali i kierunków dojazdów do pracy nabierają coraz większego znaczenia praktycznego, dostarczając ważnych argumentów w procesie integracji zarządzania na obszarach metropolitalnych (Kaczmarek, Mikuła, 2007). Ich wyniki stają się ważną przesłanką w tworzeniu polityk transportowych, planów zagospodarowania przestrzennego, a nawet odrębnych strategii mobilności, łączących w sobie zagadnienia dojazdów do szkół i miejsc pracy z kształtowaniem infrastruktury transportowej i poprawą funkcjonowania transportu publicznego (Bul, 2015).

Celem opracowania jest identyfikacja skali i kierunków dojazdów do pracy na obszarze aglomeracji poznańskiej i województwa wielkopolskiego. Niniejszy artykuł stanowi kontynuację publikacji z 2015 r. pt. „Dojazdy do pracy w aglomeracji poznańskiej w 2011 r.", w ramach której autor analizował dane o podobnym charakterze, obrazujące sytuację o pięć lat wcześniejszą. Z uwagi na znaczną skalę przemieszczeń do Poznania, szczegółowej analizie poddano dojazdy, których celem jest miasto i jego aglomeracja. Jest to szczególnie ważne zagadnienie badawcze ze względu na zjawisko migracji rezydencjalnych zachodzących na tym obszarze. Dane opublikowane przez GUS dla roku 2016 pozwoliły na określenie skali i kierunków przemieszczeń do stolicy regionu, a także wskazanie jednostek, których powiązania funkcjonalne z miastem są najsilniejsze. Szczegółowej analizie poddano także dojazdy do jednostek zlokalizowanych w powiecie poznańskim (ziemskim), przyjmujących na tle regionu, z wyłączeniem miasta centralnego, największe potoki pracownicze. Odrębnym celem było wskazanie głównych centrów migracji pracowniczych w skali regionu. Stało się to możliwe dzięki upublicznieniu przez GUS macierzy przepływów pomiędzy jednostkami terytorialnymi. Uzyskanie powyższych danych pozwoliło na przeprowadzenie pogłębionego wnioskowania oraz wskazanie lokalnych rynków pracy w ramach regionu (Bul, 2015).

W tym miejscu należy wspomnieć, że rozpoznanie przemieszczeń związanych z wykonywaniem działalności zarobkowej przez szereg lat nastręczało sporo trudności. Podstawowym problemem był brak danych statystycznych nt. kierunków i skali dojaz- 
dów. Tego typu informacje dostępne były tylko dla wybranych lat z okresu PRL, m.in. na podstawie spisów kadrowych, z których ostatni dotyczył roku 1983 (Wiśniewski, 2013). Szczęśliwie od 2006 r. co pięć lat, dzięki staraniom Głównego Urzędu Statystycznego i pracy poznańskiego oddziału GUS, publikowane są dane o przepływach ludności związanych z zatrudnieniem, przygotowane w oparciu o informacje z urzędów skarbowych, ZUS i KRUS.

Dojazdy do pracy stanowiły i stanowią interesujące pole badawcze dla ekonomistów, socjologów czy geografów. Obok pracy T. Lijewskiego z 1967 r., który jako jeden z pierwszych polskich autorów podjął się rozpoznania zjawiska w skali całego kraju, warto też przypomnieć późniejsze opracowania dotyczące przemieszczeń pracowniczych, które często bazowały na danych empirycznych pozyskanych przez badaczy. Dojazdami w ujęciu regionalnym, lokalnym i krajowym w ciągu ostatnich przeszło trzydziestu lat zajmowali się m.in. J. Kitowski (1988), J. Runge (1991), T. Gocał i W. Rakowski (1991), A. Potrykowska (1995), czy P. Śleszyński (2012) a także badacze z ośrodka poznańskiego, m.in. E. Klebba (1995), U. Kaczmarek i Ł. Mikuła (2009), P. Churski i in. (2009), H. Gruchociak (2013) czy R. Bul (2011, 2012, 2014, 2015).

\section{Zakres pracy i metody badawcze}

Dane statystyczne o dojazdach do pracy w roku 2016, w oparciu o które wykonano poniższe analizy, pochodzą z baz danych Głównego Urzędu Statystycznego. Informacje te pozyskiwane były przez GUS przy użyciu zbliżonej metodologii, jak miało to miejsce w roku 2011 (por. Bul, 2015), co pozwoliło na zaprezentowanie zjawiska w ujęciu dynamicznym. Źródło stanowiły zbiory Zakładu Ubezpieczeń Społecznych (dane w zakresie płatników składek i ubezpieczonych), Ministerstwa Finansów (dane w zakresie płatników i podatników podatku dochodowego), oraz Kasy Rolniczego Ubezpieczenia Społecznego.

Autor niniejszego opracowania po raz kolejny chciałby podkreślić, iż należy docenić pracę wykonaną przez Główny Urząd Statystyczny. Pomimo, że dane nie przedstawiają całości badanego zjawiska (brakuje np. informacji o dojazdach osób pracujących w ramach umowy o dzieło, umowy zlecenia, czy prowadzących własną działalność gospodarczą), stanowią one bardzo dobry wskaźnik mobilności oraz pozwalają na identyfikację powiązań pomiędzy jednostkami terytorialnymi. Należy jednak wskazać na inne ograniczenia wykorzystania danych. Przede wszystkim przedstawione informacje statystyczne nie powalają na identyfikację przemieszczeń na obszarach dużych miast (zgodnie z przyjętą metodologią osobą dojeżdżającą jest osoba przekraczająca granicę administracyjną), co uniemożliwia całościowe określenie skali dojazdów. Nie ukazują także przemieszczeń w różnych cyklach czasowych - tygodniowych, dobowych i rzadszych. Ponadto dużym ograniczeniem wykorzystania danych jest ich aktualność oraz częstotliwość pozyskiwania i publikowania. Nie zmienia to jednak faktu, iż dostępne informacje są niezwykle cenne, oraz pozwalają na identyfikację powiązań funkcjonalnych i przemieszczeń ludności pomiędzy poszczególnymi jednostkami.

W artykule, bazując na danych dla 2016 r., analizie poddano zjawisko dojazdów do pracy na obszarze aglomeracji poznańskiej i województwa wielkopolskiego w ujęciu krajowym, regionalnym i lokalnym. Ze względu na niewielkie znaczenie dojazdów spoza obszaru województwa, zagadnienia tego nie analizowano w sposób szczegółowy. Wykorzystano dane zarówno w formie gotowych tabel (zaprezentowanych w publikacji GUS "Dojazdy do pracy w województwie wielkopolskim w 2016 r."), jak i informacje statystyczne upublicznione na stronie internetowej Urzędu (w zakładce "Opracowania”, jako tytuł „Przepływy ludności związane z zatrudnieniem w 2016 r."). Podstawowymi metodami stosowanymi w pracy były: metoda wskaźnikowa, analiza macierzy przepływów, a także kartograficzne metody prezentacji w postaci kartodiagramów i kartogramów. Wizualizacji przepływów dokonano przy wykorzystaniu oprogramowania Esri ArcGIS w wersji 10.4. Analizy statystyczne wykonywano przy użyciu programu StatSoft Statistica w wersji 10.

\section{Dojazdy do pracy w ujęciu krajowym}

Z danych opublikowanych przez Główny Urząd Statystyczny wynika, że w Polsce w 2016 r. dojeżdżało do pracy 3,27 mln pracowników najemnych, co stanowiło 30,6\% ogólnej ich liczby. Powyższa informacja statystyczna wskazuje na wzrost liczby osób dojeżdżających do pracy w porównaniu z rokiem 2006 i 2011. Co ciekawe, wzrost ten nastąpił w największych aglomeracjach, ale nie dotyczył samych miast, z których tylko nieliczne poszerzyły swój zasięg oddziaływania. Przyrost odnotowały głównie gminy podmiejskie, zlokalizowane $w$ tych aglomeracjach.

W 2016 r. najwięcej osób dojeżdżających do pracy poza granice własnej gminy zamieszkiwało województwo śląskie - 514,8 tys. osób, co stanowiło 15,7\% migrantów pracowniczych ogółem. Znaczną liczbę dojeżdżających do pracy zanotowano w województwach: wielkopolskim (398 tys.) i mazowieckim (376 tys. - 11,4\%). Najmniej takich osób zamieszkiwało województwo podlaskie (49,4 tys.).

Spośród polskich miast największym ośrodkiem dojazdów była Warszawa, do której przyjeżdżało 251 
tys. osób. Drugim ośrodkiem dojazdów były Katowice, stanowiące centrum Górnośląskiego Okręgu Przemysłowego (114 tys.). Trzecie miejsce w kraju zajmował Poznań (awans z czwartego miejsca w roku 2011) z liczbą osób przyjeżdżających wynoszącą blisko 86 tys. (tab. 1). W większości dużych miast wystąpił jednak spadek liczby przyjazdów pracowniczych.

Dane opublikowane przez GUS wskazują, że miasto Poznań oraz otaczający je powiat poznański stanowią na tle kraju jeden z największych ośrodków dojazdów do pracy. Sam powiat pod względem liczby osób przyjeżdżających zajmuje piątą pozycję wśród wszystkich jednostek powiatowych i bezwzględnie pierwszą wśród powiatów ziemskich. Powyższe wyniki wskazują, że miasto i powiat stanowią największy rynek pracy w zachodniej Polsce, a o ekonomicznym potencjale aglomeracji świadczą przede wszystkim drugi najwyższy wskaźnik PKB per capita w kraju (po Warszawie) i najniższa w Polsce stopa bezrobocia (Bul, 2015). Przytoczone wyniki pozwalają ponadto na stwierdzenie, że cała aglomeracja poznańska stanowi trzeci największy ośrodek dojazdów do pracy w Polsce z liczbą ponad 165 tys. osób przyjeżdżających.

O sile powiązań przestrzennych i funkcjonalnych zachodzących na obszarze aglomeracji poznańskiej świadczą dane o liczbie osób wyjeżdżających do pracy z danej jednostki. Okazuje się, że powiat poznański cechuje się największą w skali kraju liczbą osób wy- jeżdżających do pracy (ponad 66 tys.). Jednocześnie miasto Poznań zajmuje w tej klasyfikacji miejsce trzecie (ponad 27 tys. osób; tab. 2). Dane te potwierdzają istnienie silnego rynku pracy o znaczeniu aglomeracyjnym (Bul, 2015). Jest to skutek coraz mniejszego zróżnicowania gospodarczego miasta centralnego i gmin otaczających. Wiele nowych dużych zakładów pracy lokuje się przy granicy miasta w gminach sąsiadujących, położonych przy najważniejszych szlakach komunikacyjnych. Co więcej, w najbliższych latach prognozuje się zwiększenie liczby miejsc pracy w gminach podpoznańskich kosztem pewnej liczby miejsc w mieście centralnym (Bul, 2011).

Dane GUS dla roku 2016 obrazują ponadprzeciętną skalę przemieszczeń na obszarze aglomeracji poznańskiej. Saldo dojazdów w Poznaniu, podobnie jak w przypadku innych dużych miast, jest wybitnie dodatnie i wynosi ponad 58,5 tys. osób. Także jednostki powiatu poznańskiego cechuje łączne dodatnie saldo (ok. 13 tys.), przy czym należy wspomnieć, że dane z roku 2006 wskazywały na istnienie salda ujemnego. Wielkość obrotu migracyjnego sytuuje miasto na czwartej, a powiat na drugiej pozycji w kraju (po Warszawie). Warto dodać, że 19. miejsce w skali kraju pod względem liczby przyjeżdżających zajmuje Tarnowo Podgórne (17 tys.), lokując się na pierwszym miejscu wśród gmin podmiejskich wchodzących w skład aglomeracji.

Tab. 1. Liczba przyjeżdżających, wyjeżdżających, saldo dojazdów i obrót migracyjny według powiatów.

\begin{tabular}{|c|c|c|c|c|c|}
\hline Lp. & $\begin{array}{l}\text { Jednostka miejsca } \\
\text { pracy / zamieszkania }\end{array}$ & $\begin{array}{c}\text { Liczba } \\
\text { przyjeżdżających }\end{array}$ & Liczba wyjeżdżających & Saldo dojazdów & Obrót migracyjny* \\
\hline 1 & Warszawa & 251021 & 30595 & 220426 & 281616 \\
\hline 2 & Katowice & 113830 & 19299 & 94531 & 133129 \\
\hline 3 & Poznań & 85896 & 27368 & 58528 & 113264 \\
\hline 4 & Kraków & 84027 & 19905 & 64122 & 103932 \\
\hline 5 & powiat poznański & 79498 & 66463 & 13035 & 145961 \\
\hline 6 & Wrocław & 69345 & 17297 & 52048 & 86642 \\
\hline 7 & Łódź & 48389 & 15476 & 32913 & 63865 \\
\hline 8 & Rzeszów & 46855 & 7952 & 38903 & 54807 \\
\hline 9 & Gdańsk & 40781 & 17879 & 22902 & 58660 \\
\hline 10 & Lublin & 36700 & 7823 & 28877 & 44523 \\
\hline
\end{tabular}

* suma liczby osób przyjeżdżających i wyjeżdżających z jednostki 
Tab. 2. Liczba wyjeżdżających według powiatów.

\begin{tabular}{|r|l|c|}
\hline Lp. & $\begin{array}{c}\text { Jednostka miejsca } \\
\text { zamieszkania }\end{array}$ & $\begin{array}{c}\text { Liczba } \\
\text { wyjeżdżających }\end{array}$ \\
\hline 1 & powiat poznański & 66463 \\
\hline 2 & Warszawa & 30595 \\
\hline 3 & Poznań & 27368 \\
\hline 4 & Sosnowiec & 24277 \\
\hline 5 & Kraków & 19905 \\
\hline 6 & Katowice & 19299 \\
\hline 7 & Bytom & 17907 \\
\hline 8 & Gdańsk & 17879 \\
\hline 9 & Wrocław & 17297 \\
\hline 10 & Zabrze & 16880 \\
\hline
\end{tabular}

Źródło: opracowanie własne na podstawie danych GUS, 2019.

\section{Dojazdy do pracy w województwie wielkopolskim i aglomeracji poznańskiej}

Aglomeracja poznańska stanowi aktualnie jeden z najlepiej rozwiniętych gospodarczo obszarów w kraju i obok aglomeracji warszawskiej, krakowskiej, wrocławskiej i trójmiejskiej jest jednym z wiodących biegunów wzrostu w Polsce. Na silną pozycję regionu wskazują również informacje statystyczne dotyczące skali i kierunków przemieszczeń pracowniczych. Analizując strukturę przestrzenną dojazdów pracowniczych należy stwierdzić, że największy pod tym względem ośrodek, którym jest miasto Poznań, stanowi cel przede wszystkim dla mieszkańców środkowej części regionu wielkopolskiego.

W 2016 r. Poznań był miejscem pracy dla 85,9 tys. pracowników najemnych mieszkających poza jego granicami, co w porównaniu z poprzednim badaniem z 2011 r. oznacza spadek o 5,4\%. Większość zatrudnionych ( 72,0 tys., tj. 83,9\%) pochodziła z gmin województwa wielkopolskiego, natomiast pozostali $(13,9$ tys., tj. 16,1\%) przyjeżdżali do Poznania z innych województw. Ponad połowa przyjeżdżających wywodziła się z terenów wiejskich $(56,0 \%)$, co w porównaniu z 2011 r. oznacza zmianę tendencji, bowiem udziały miast i obszarów wiejskich kształtowały się wówczas na zbliżonym poziomie, jednak z niewielką przewagą miast $(50,7 \%$ wobec $49,3 \%$ przyjeżdżających z terenów wiejskich). Bardziej mobilni byli mężczyźni, którzy stanowili 55,6\% ogółu przyjeżdżających (w 2011 r. $55,1 \%)$. Biorąc pod uwagę wiek przyjeżdżających, zgodnie z ogólną tendencją dominowały dwie grupy: 25-34 oraz 35-44 lata, jednak w przypadku Poznania w 2016 r. większy odsetek stanowiła "starsza” grupa (30,2\% wobec $25,8 \%$; w 2011 r. 25,4\% wobec 33,7\%).

Najwięcej osób przyjeżdżających do pracy do Poznania mieszkało w jednostkach graniczących z miastem, tj. gminach: Swarzędz (łącznie miasto i obszar wiejski - ponad 5 tys. osób), Czerwonak (ponad 3,4 tys. osób), Luboń (3,4 tys.) oraz Komorniki (2,6 tys.). Intensywne dojazdy cechowały także większe miasta regionu, tj. Gniezno (1,8 tys.) i Wrześnię (miasto - 1,1 tys.) (tab. 3, ryc. 1). Łącznie przemieszczenia o skali większej niż 100 osób cechowały 152 jednostki (spadek o 4 w porównaniu z 2011 r.), w tym 143 z obszaru województwa wielkopolskiego.

Tab. 3. Liczba przyjeżdżających do pracy do Poznania.

\begin{tabular}{|r|l|r|r|l|c|}
\hline Lp. & \multicolumn{1}{|c|}{ Jednostka miejsca zamieszkania } & Liczba osób & \multicolumn{1}{|c|}{ Lp. } & \multicolumn{1}{|c|}{ Jednostka miejsca zamieszkania } & Liczba osób \\
\hline 1 & Czerwonak & 3423 & 11 & Suchy Las & 1514 \\
\hline 2 & Luboń & 3394 & 12 & Rokietnica & 1470 \\
\hline 3 & Swarzędz - miasto & 3270 & 13 & Września - miasto & 1143 \\
\hline 4 & Komorniki & 2630 & 14 & Murowana Goślina - miasto & 1034 \\
\hline 5 & Dopiewo & 1784 & 16 & Mosina - miasto & 1021 \\
\hline 6 & Gniezno & 1778 & 17 & Kleszczewo & 959 \\
\hline 7 & Swarzędz - obszar wiejski & 1682 & 18 & Kościan & 811 \\
\hline 8 & Tarnowo Podgórne & 1526 & 19 & Pobiedziska - miasto & 797 \\
\hline 9 & Kórnik - obszar wiejski & 1515 & 20 & Pobiedziska - obszar wiejski & 772 \\
\hline 10 & Mosina - obszar wiejski & Kostrzyn - miasto & 760 \\
\hline
\end{tabular}

Źródło: opracowanie własne na podstawie danych GUS, 2019. 


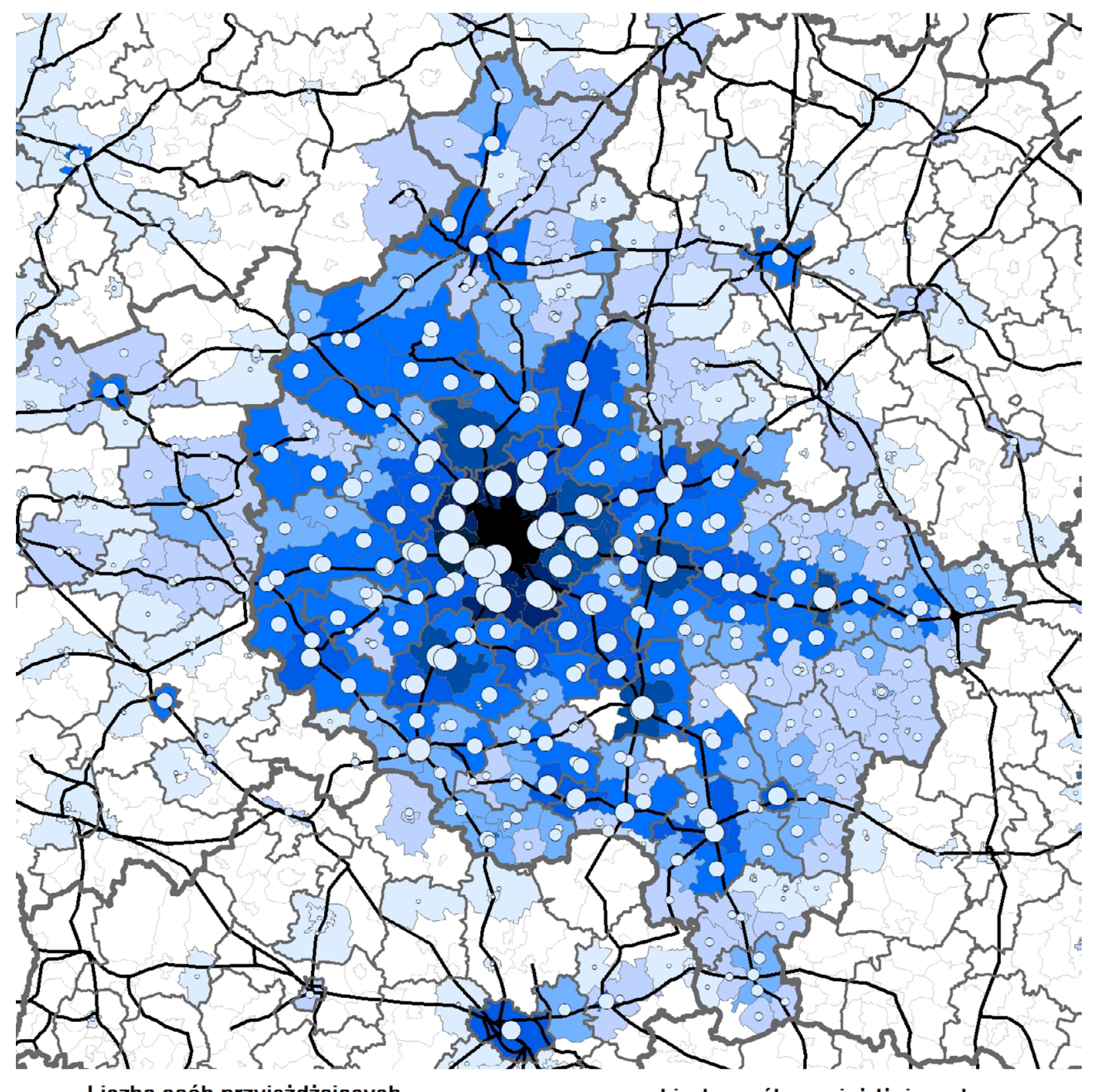
Liczba osób przyjeżdżających

$$
\begin{aligned}
& \text { > } 2000 \\
& 1000-2000 \\
& \bigcirc 500-1000 \\
& 200-500 \\
& \quad 100-200 \\
& \quad 50-100 \\
& \quad 20-50 \\
& \quad 10-20 \\
& <10
\end{aligned}
$$

Liczba osób przyjeżdżających
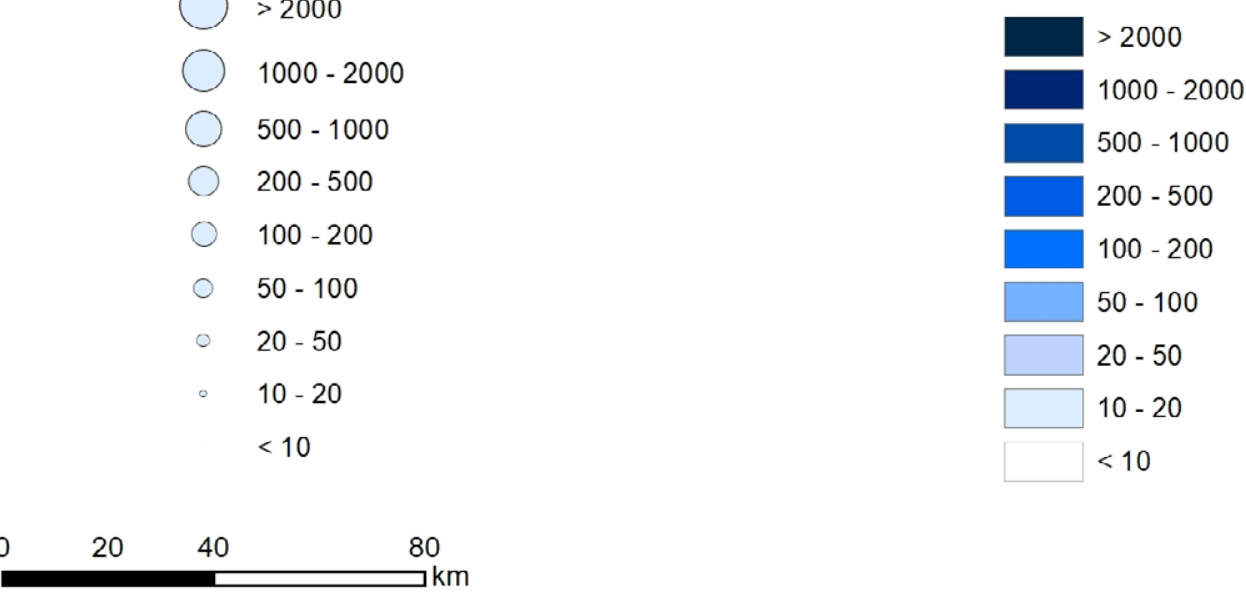

Ryc. 1. Przyjazdy do pracy do miasta Poznania.

Źródło: opracowanie własne na podstawie danych GUS, 2019. 
Przytoczone dane potwierdzają, że Poznań należy do największych ośrodków dojazdów do pracy w Polsce. Miasto stanowi centrum dojazdów nie tylko dla mieszkańców powiatu poznańskiego, ale także gmin leżących poza powiatem zlokalizowanych w odległości do $70 \mathrm{~km}$ od miasta. Są to jednostki gminne położone głównie w powiatach: szamotulskim, nowotomyskim, kościańskim, średzkim, wrzesińskim, gnieźnieńskim, wągrowieckim i obornickim. Ważnym wskaźnikiem prezentującym powiązania w zakresie dojazdów do pracy jest również udział liczby przyjeżdżających do pracy w Poznaniu w ogólnej liczbie wyjeżdżających w gminie zamieszkania (ryc. 2). Gminy, z których w 2016 r. przyjeżdżał największy odsetek zamieszkałych w nich pracowników najemnych, koncentrują się pierścieniowo wokół granic miasta. Dodatkowo znaczny odsetek dojeżdża z jednostek dobrze z miastem skomunikowanych, położonych przy najważniejszych szlakach kolejowych i drogowych. Podobnie jak w 2011 r. najwyższe wartości wskaźnika wystąpiły w gminach powiatu poznańskiego: w Czerwonaku (gmina wiejska), Luboniu (gmina miejska), Swarzędzu (część miejska), Kostrzynie (część miejska), Suchym Lesie (gmina wiejska), Kleszczewie (gmina wiejska) oraz Rokietnicy (gmina wiejska).

Ważną miarą określającą siłę powiązań miasta z jednostkami zlokalizowanymi w powiecie poznań- skim jest liczba osób wyjeżdżających z miasta Poznania do pracy w innych jednostkach osadniczych. W 2016 r. było to łącznie ponad 27 tys. poznaniaków. Poza region wyjeżdżali oni najczęściej do jednostek zlokalizowanych w województwie mazowieckim, dolnośląskim i kujawsko-pomorskim. Najliczniejsza grupa pracowała w Warszawie (2,5 tys. osób) i Wrocławiu (296 osób).

Największą skalą wyjazdów z Poznania cechowały się gminy podmiejskie, $w$ tym przede wszystkim: Tarnowo Podgórne (5,4 tys. osób), Komorniki (2,4 tys.), Suchy Las (2,1 tys.), Swarzędz - obszar wiejski (1,3 tys.) oraz Kórnik - obszar wiejski (1,3 tys.). Ogółem wyjazdy o skali większej niż 100 osób dotyczyły 29 jednostek, w tym 25 z obszaru województwa wielkopolskiego (ryc. 3).

Interesujące wyniki przynosi analiza udziału wyjeżdżających do pracy z Poznania w ogólnej liczbie przyjeżdżających do gmin. Okazuje się, że coraz więcej osób pracuje w gminach graniczących z miastem, z uwagi na wzrost liczby miejsc pracy na ich obszarze (szczególnie w jednostkach położonych przy głównych szlakach komunikacyjnych). Poznaniacy stanowią ponad $20 \%$ osób dojeżdżających do Tarnowa Podgórnego, Dopiewa, Komornik, Rokietnicy, Suchego Lasu, Czerwonaka, Swarzędza i Pobiedzisk. Powyższe wartości wskazują na silne powiązania we-

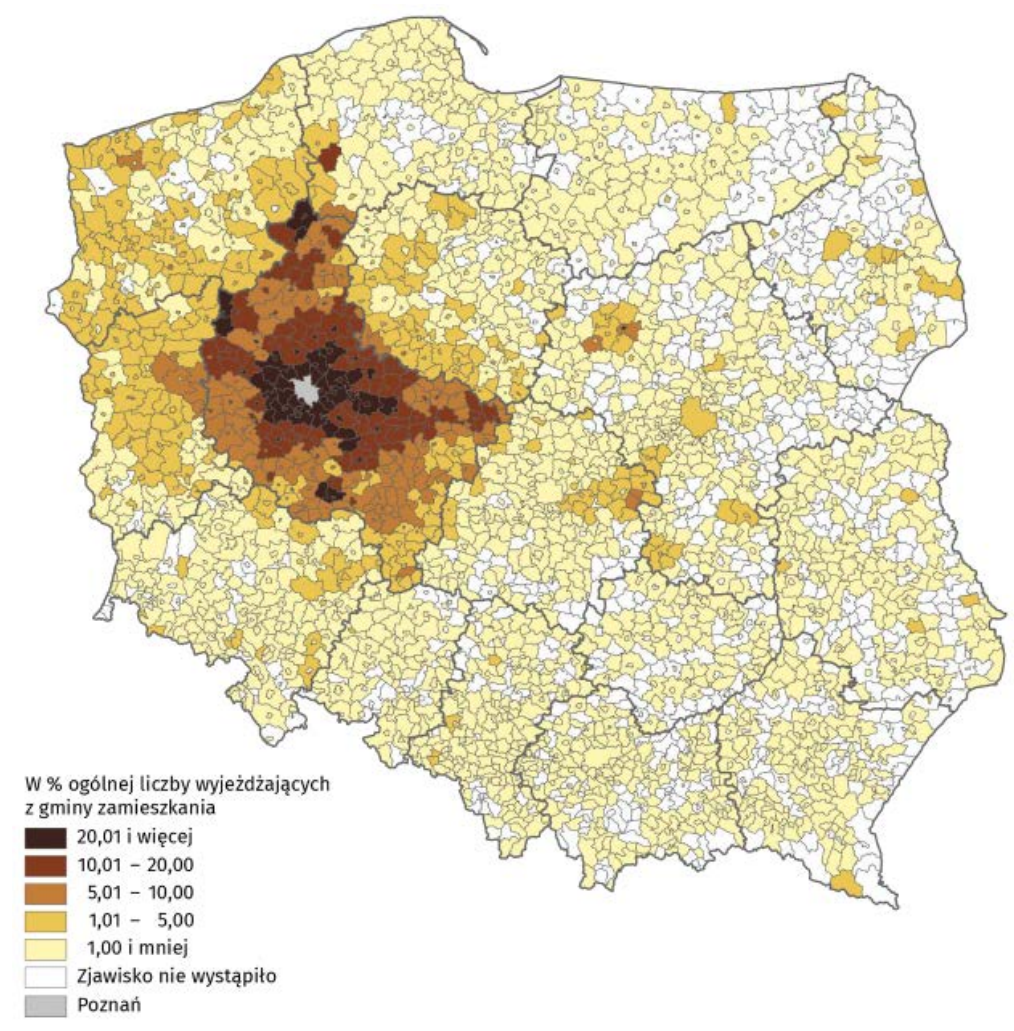

Ryc. 2. Udział przyjeżdżających do pracy do Poznania w ogólnej liczbie wyjeżdżających w gminie zamieszkania. 


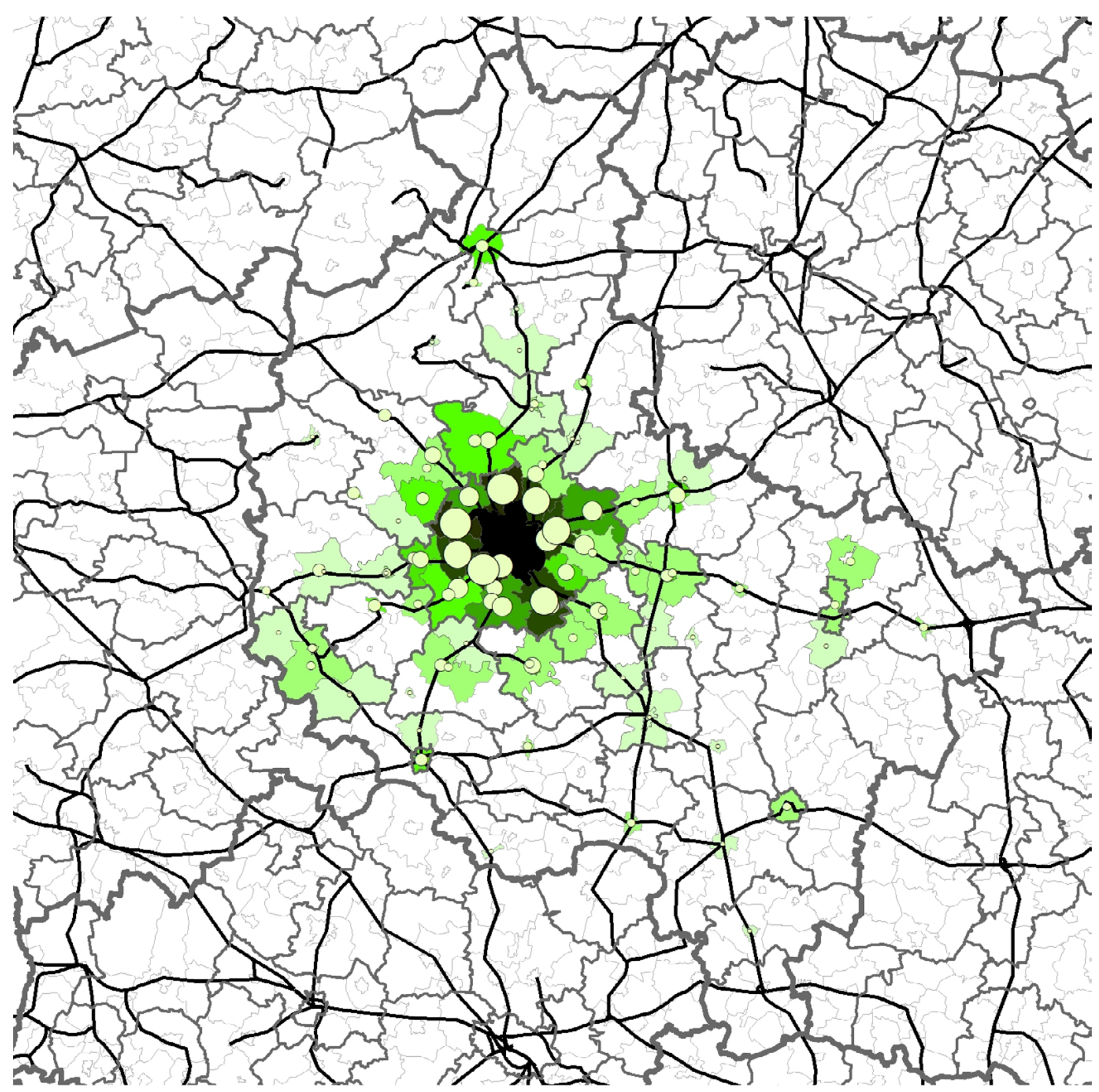
Liczba osób wyjeżdżających

$$
\begin{aligned}
& \text { ( > } 2000 \\
& \text { ( } 1000-2000 \\
& \text { ( } 500-1000 \\
& \text { ○ } 200-500 \\
& \text { - } 100-200 \\
& \text { - } 50-100 \\
& \text { - } 20-50 \\
& 10-20 \\
& <10
\end{aligned}
$$

Liczba osób wyjeżdżających

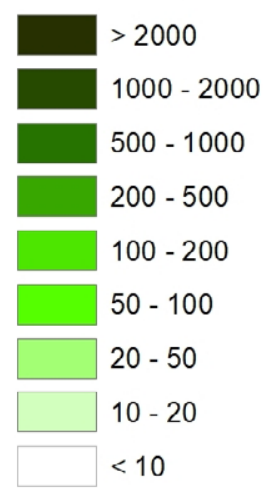




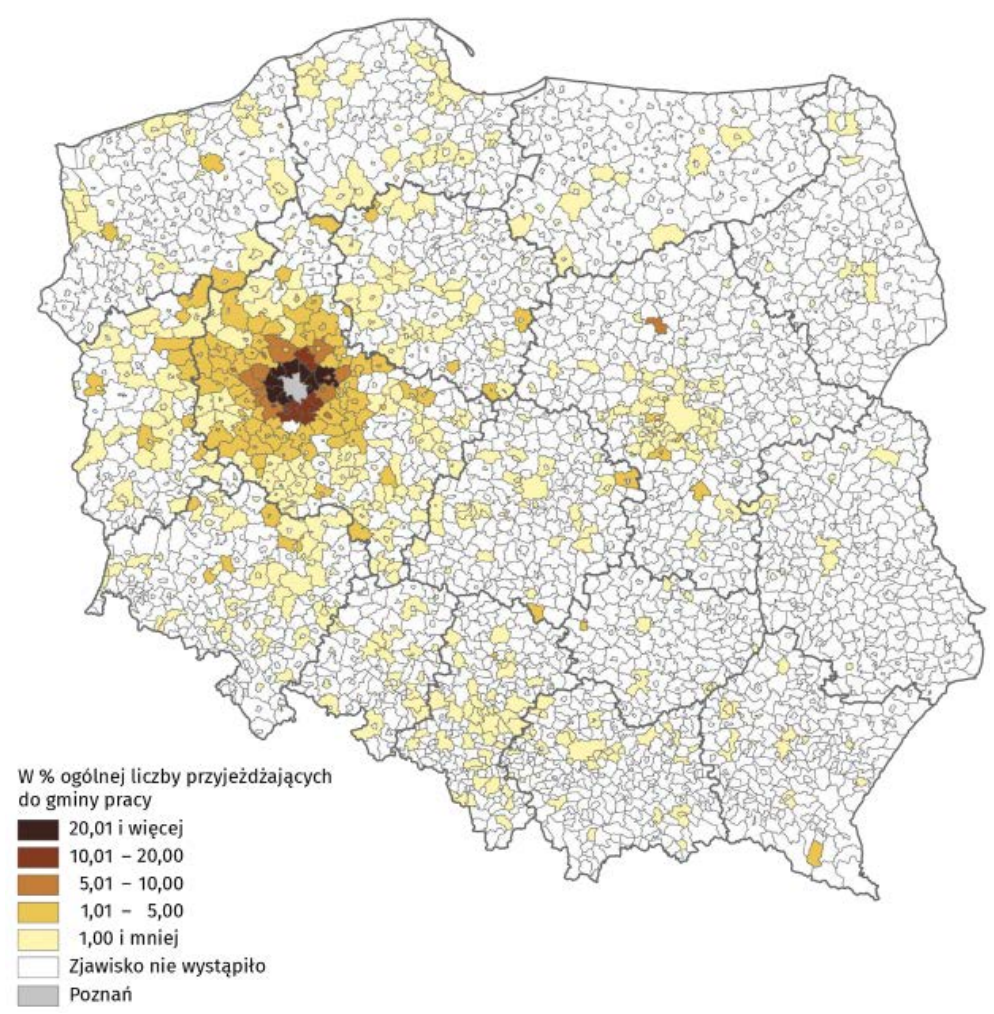

Ryc. 4. Udział wyjeżdżających z Poznania do pracy w ogólnej liczbie przyjeżdżających do gmin.

Źródło: opracowanie własne na podstawie danych GUS, 2019.

wnątrz samej aglomeracji, na obszarze której znajdują się jednostki gminne o coraz silniej rozwiniętym rynku pracy (Bul, 2015).

Obok Poznania znaczącymi ośrodkami dojazdów pracowniczych w województwie wielkopolskim są gminy wchodzące w skład aglomeracji stolicy regionu oraz ośrodki subregionalne, do których najczęściej zalicza się: Piłę, Kalisz, Konin, Ostrów Wlkp., Leszno i Gniezno. Dane publikowane przez GUS wskazują, że drugim największym ośrodkiem dojazdów w województwie jest gmina Tarnowo Podgórne (blisko 17 tys. osób). Trzecie miejsce w tym zestawieniu zajmuje inna gmina aglomeracji, tj. Komorniki (10 tys. osób przyjeżdżających). Dopiero na czwartym miejscu w regionie lokuje się Kalisz - drugie pod względem zaludnienia miasto województwa. Powyższe dane wskazują na duże znaczenie aglomeracyjnego rynku pracy na tle całego województwa oraz świadczą o silnych powiązaniach gmin wchodzących w jej skład, czego identyfikatorem są intensywne przepływy pracownicze (Bul, 2015). Jest to efekt rozwoju gmin podmiejskich w ostatnich latach. Porównanie danych dotyczących skali dojazdów wskazuje na znaczny wzrost liczby osób dojeżdżających do gmin podpoznańskich.
Z kolei dane o liczbie osób wyjeżdżających do pracy obrazują znaczną skalę mobilności w ramach samej aglomeracji. Obok Poznania największą liczbą osób wyjeżdżających do pracy cechują się gminy podmiejskie, tj. Luboń, Swarzędz, Czerwonak, Komorniki i Dopiewo oraz ośrodki zlokalizowane w strefie oddziaływania Poznania i jego aglomeracji, czyli Gniezno oraz Śrem. Znaczna skala przemieszczeń występuje także pomiędzy głównymi ośrodkami aglomeracji kalisko-ostrowskiej (tab. 4, ryc. 5-6).

Aglomeracja poznańska i region wielkopolski są obszarem bardzo zróżnicowanym pod względem gospodarczym, na co największy wpływ ma zagospodarowanie przestrzenne jednostek administracyjnych (Bul, 2015). Obok jednostek o charakterze przemysłowo-usługowym (np. Tarnowo Podgórne), rezydencjalnym (Puszczykowo), funkcjonują też gminy typowo rolnicze (np. Kleszczewo). Z tego względu zróżnicowanie skali dojazdów do pracy w regionie jest znaczące. Wskaźnikami pozwalającymi na określenie znaczenia danej jednostki w strukturze dojazdów są: saldo i iloraz przepływów (tab. 5, ryc. 7-8).

Dodatnie saldo przemieszczeń cechuje przede wszystkim duże ośrodki (Poznań i miasta subregionalne) oraz ich strefy podmiejskie. Na tym tle wy- 
Tab. 4. Liczba przyjeżdżających i wyjeżdżających do pracy w województwie wielkopolskim.

\begin{tabular}{|r|l|c|r|l|r|}
\hline \multicolumn{1}{|c|}{$\begin{array}{c}\text { Lp. } \\
\text { miejsca pracy }\end{array}$} & $\begin{array}{c}\text { Liczba } \\
\text { przyjeżdżających }\end{array}$ & \multicolumn{1}{|c|}{$\begin{array}{c}\text { Lp. } \\
\text { Jednostka } \\
\text { miejsca zamieszkania }\end{array}$} & $\begin{array}{c}\text { Liczba } \\
\text { wyjeżdżających }\end{array}$ \\
\hline 1 & Poznań & 85896 & 1 & Poznań & 27368 \\
\hline 2 & Tarnowo Podgórne & 16869 & 2 & Luboń & 5758 \\
\hline 3 & Komorniki & 10402 & 3 & Swarzędz - miasto & 5668 \\
\hline 4 & Kalisz & 9584 & 4 & Czerwonak & 5328 \\
\hline 5 & Leszno & 8102 & 5 & Gniezno & 5145 \\
\hline 6 & Konin & 7932 & 6 & Komorniki & 4878 \\
\hline 7 & Ostrów Wielkopolski & 7897 & Ostrów Wielkopolski & 4773 \\
\hline 8 & Kórnik - obszar wiejski & 7652 & 8 & Kalisz & 4696 \\
\hline 9 & Swarzędz - obszar wiejski & 5936 & 9 & Dopiewo & 4259 \\
\hline 10 & Krotoszyn - miasto & 5888 & 10 & Śrem - miasto & 4065 \\
\hline
\end{tabular}

Źródło: GUS, 2014.

różnia się aglomeracja poznańska, gdzie w 2016 r. aż 10 jednostek odnotowało dodatnie saldo dojazdów. Były to obok Poznania: Tarnowo Podgórne, Kórnik (obszar wiejski), Suchy Las, Swarzędz (obszar wiejski), Komorniki, miasto i obszar wiejski gminy Buk, miasto Kostrzyn i miasto Stęszew.

Na drugim biegunie w ramach aglomeracji znajdują się jednostki o mniejszym potencjale gospodarczym, które jednocześnie cechują od wielu lat silnie powiązania z miastem centralnym (Bul, 2015). Duże saldo ujemne dojazdów dotyczy przede wszystkim miast: Lubonia, Mosiny i Swarzędza (z uwagi na bliskość Poznania), a także obszarów wiejskich gmin: Kostrzyn, Mosina, Murowana Goślina oraz gminy wiejskiej Rokietnica.
Interesującym wskaźnikiem jest także iloraz przepływów, czyli stosunek liczby osób przyjeżdżających do wyjeżdżających. Wskaźnik przyjmuje wartości powyżej 1 dla gmin z dodatnim saldem dojazdów. Pod tym względem w obrębie aglomeracji wyróżniają się Poznań $(3,14)$ i Tarnowo Podgórne $(5,53)$. Ponadto w skali regionu wysoki iloraz charakteryzował również gminę wiejską Powidz (5,43), część wiejską gminy Nowe Skalmierzyce $(4,68)$, miasto Wronki $(4,53)$ oraz gminę miejską Koło $(4,4)$. Najniższe wartości ilorazu przepływów występowały w gminach i obszarach wiejskich, gdzie liczba wyjeżdżających pracowników najemnych wielokrotnie przewyższała liczbę przyjeżdżających do pracy. Najniższy w regionie iloraz dotyczył gmin: Ostroróg (obszar wiejski), Rzgów i Soś-

Tab. 5. Liczba przyjeżdżających, wyjeżdżających, obrót migracyjny i saldo dojazdów do pracy w Poznaniu i jednostkach powiatu poznańskiego.

\begin{tabular}{|c|c|c|c|c|c|c|}
\hline Lp. & $\begin{array}{c}\text { Jednostka } \\
\text { miejsca zamieszkania }\end{array}$ & $\begin{array}{c}\text { Liczba } \\
\text { przyjeżdżających }\end{array}$ & $\begin{array}{c}\text { Liczba } \\
\text { wyjeżdżających }\end{array}$ & $\begin{array}{c}\text { Obrót } \\
\text { migracyjny }\end{array}$ & $\begin{array}{c}\text { Saldo } \\
\text { dojazdów }\end{array}$ & $\begin{array}{c}\text { lloraz } \\
\text { przepływów }\end{array}$ \\
\hline 1 & Buk - miasto & 1108 & 1063 & 2171 & 45 & 1,04 \\
\hline 2 & Buk - obszar wiejski & 1488 & 1200 & 2688 & 288 & 1,24 \\
\hline 3 & Czerwonak & 4728 & 5328 & 10056 & -600 & 0,89 \\
\hline 4 & Dopiewo & 3165 & 4259 & 7424 & -1094 & 0,74 \\
\hline 5 & Kleszczewo & 775 & 1599 & 2374 & -824 & 0,48 \\
\hline 6 & Komorniki & 10402 & 4878 & 15280 & 5524 & 2,13 \\
\hline 7 & Kostrzyn - miasto & 3259 & 1937 & 5196 & 1322 & 1,68 \\
\hline 8 & Kostrzyn - obszar wiejski & 464 & 1757 & 2221 & -1293 & 0,26 \\
\hline 9 & Kórnik - miasto & 869 & 1347 & 2216 & -478 & 0,65 \\
\hline 10 & Kórnik - obszar wiejski & 7652 & 2960 & 10612 & 4692 & 2,59 \\
\hline
\end{tabular}




\begin{tabular}{|r|l|r|r|r|r|r|}
\hline 11 & 2414 & 5758 & 8172 & -3344 & 0,42 \\
\hline 12 & Losina - miasto & 1075 & 2298 & 3373 & -1223 & 0,47 \\
\hline 13 & Mosina - obszar wiejski & 1398 & 3347 & 4745 & -1949 & 0,42 \\
\hline 14 & Murowana Goślina - miasto & 1269 & 2333 & 3602 & -1064 & 0,54 \\
\hline 15 & Murowana Goślina - obszar wiejski & 231 & 1351 & 1582 & -1120 & 0,17 \\
\hline 16 & Pobiedziska - miasto & 720 & 1599 & 2319 & -879 & 0,45 \\
\hline 17 & Pobiedziska - obszar wiejski & 1261 & 1855 & 3116 & -594 & 0,68 \\
\hline 18 & Puszczykowo & 1200 & 1341 & 2541 & -141 & 0,89 \\
\hline 19 & Rokietnica & 1196 & 3020 & 4216 & -1824 & 0,40 \\
\hline 20 & Stęszew - miasto & 1983 & 1066 & 3049 & 917 & 1,86 \\
\hline 21 & Stęszew - obszar wiejski & 5006 & 1678 & 2859 & -497 & 0,70 \\
\hline 22 & Suchy Las & 3849 & 2469 & 7475 & 2537 & 2,03 \\
\hline 23 & Swarzędz - miasto & 5936 & 3668 & 9517 & -1819 & 0,68 \\
\hline 24 & Swarzędz - obszar wiejski & 16869 & 35896 & 9240 & 2632 & 1,80 \\
\hline 25 & Tarnowo Podgórne & 368 & 113264 & 58528 & 5,53 \\
\hline 26 & Poznań & 19917 & 13821 & 3,14 \\
\hline
\end{tabular}

Źródło: opracowanie własne na podstawie danych GUS, 2019.

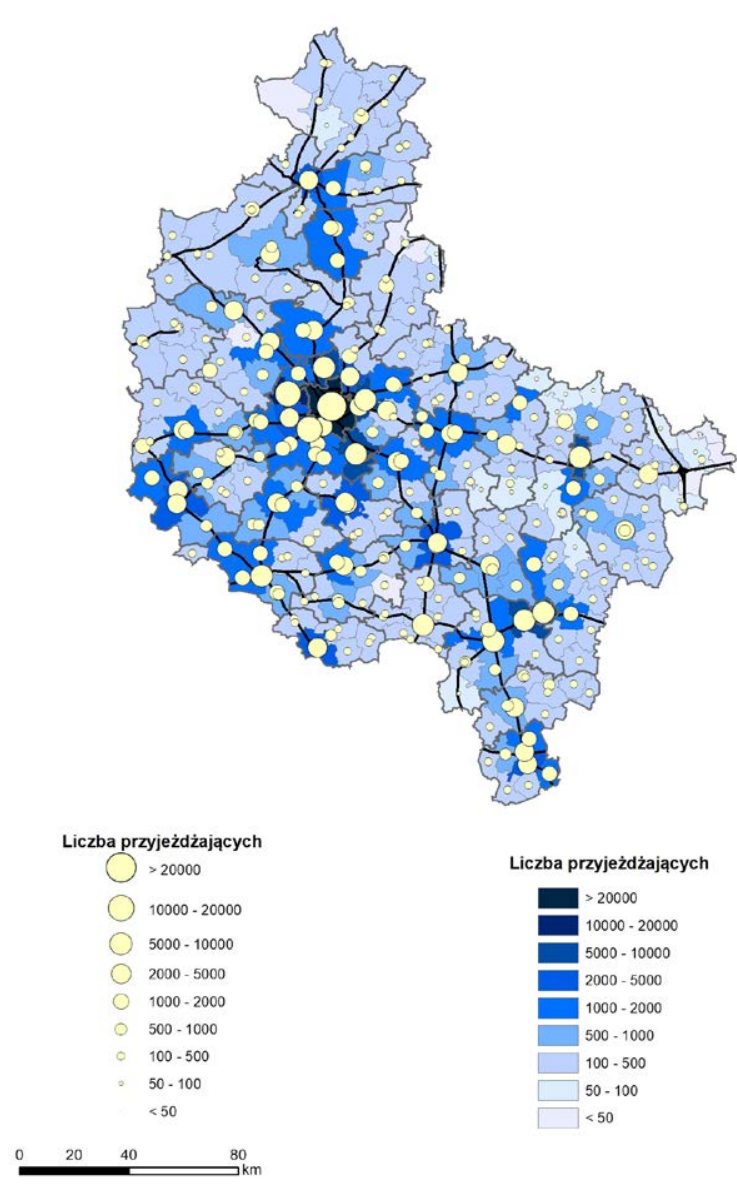

Ryc. 5. Liczba osób przyjeżdżających do pracy w gminach województwa wielkopolskiego.

Źródło: opracowanie własne na podstawie danych GUS, 2019.

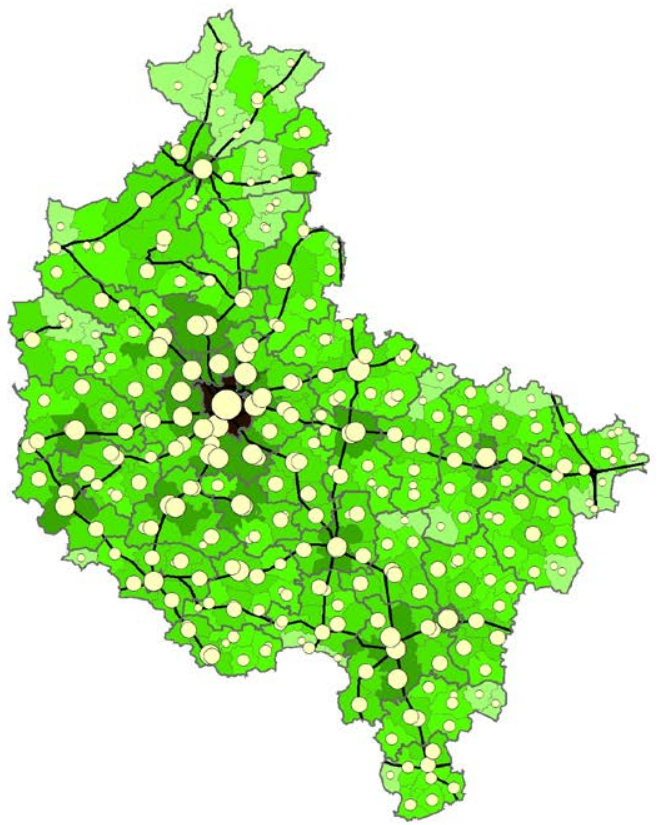

Liczba wyjeżdżających

>
$>100000-20000$
$5000-10000$
$2000-5000$
$1000-2000$
$500-1000$
$100-500$
$50-100$
$<50$
$40 \quad 80$
$\quad 50$

Liczba wyjeżdżających

$>20000$

$10000-20000$

$5000-10000$

$2000-5000$

$1000 \cdot 2000$ $500-1000$

$100-500$

$100-500$

$<50$

Ryc. 6. Liczba osób wyjeżdżających do pracy w gminach województwa wielkopolskiego.

Źródło: opracowanie własne na podstawie danych GUS, 2019. 


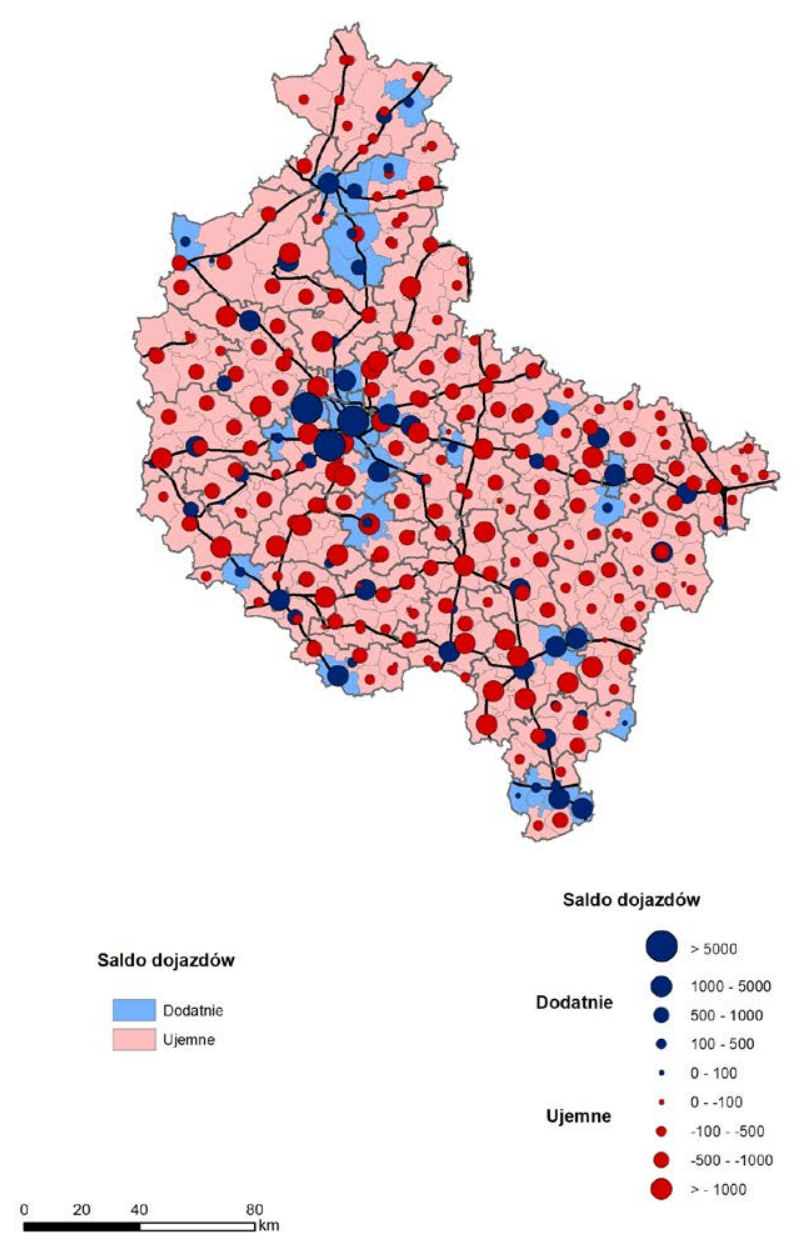

Ryc. 7. Saldo dojazdów do pracy w gminach województwa wielkopolskiego.

Źródło: opracowanie własne na podstawie danych GUS, 2019.

nie, a na obszarze aglomeracji poznańskiej Kostrzyn - obszar wiejski i Murowaną Goślinę - obszar wiejski.

Szczególnie interesujące wyniki przedstawia analiza przemieszczeń do największych ośrodków dojazdów pracowniczych w aglomeracji poznańskiej, tj. Tarnowa Podgórnego, Komornik oraz Kórnika obszaru wiejskiego (ryc. 9, 10 i 11). W zależności od skali dojazdów strefa oddziaływania poszczególnych ośrodków obejmuje obszar ograniczony ekwidystantą 30-40 km. Dostrzega się także wyraźne oddziaływanie układu transportowego, czego dowodem jest intensyfikacja dojazdów z jednostek położonych przy szlakach transportowych prowadzących do danej jednostki.

Informacje statystyczne potwierdzają silne oddziaływanie gmin wchodzących w skład powiatu poznańskiego na mieszkańców pozostałych gmin aglomeracji. Szczególnie wyraźnie widoczne jest to w przypadku Tarnowa Podgórnego, którego strefa oddziaływania jest większa aniżeli pozostałych jed-
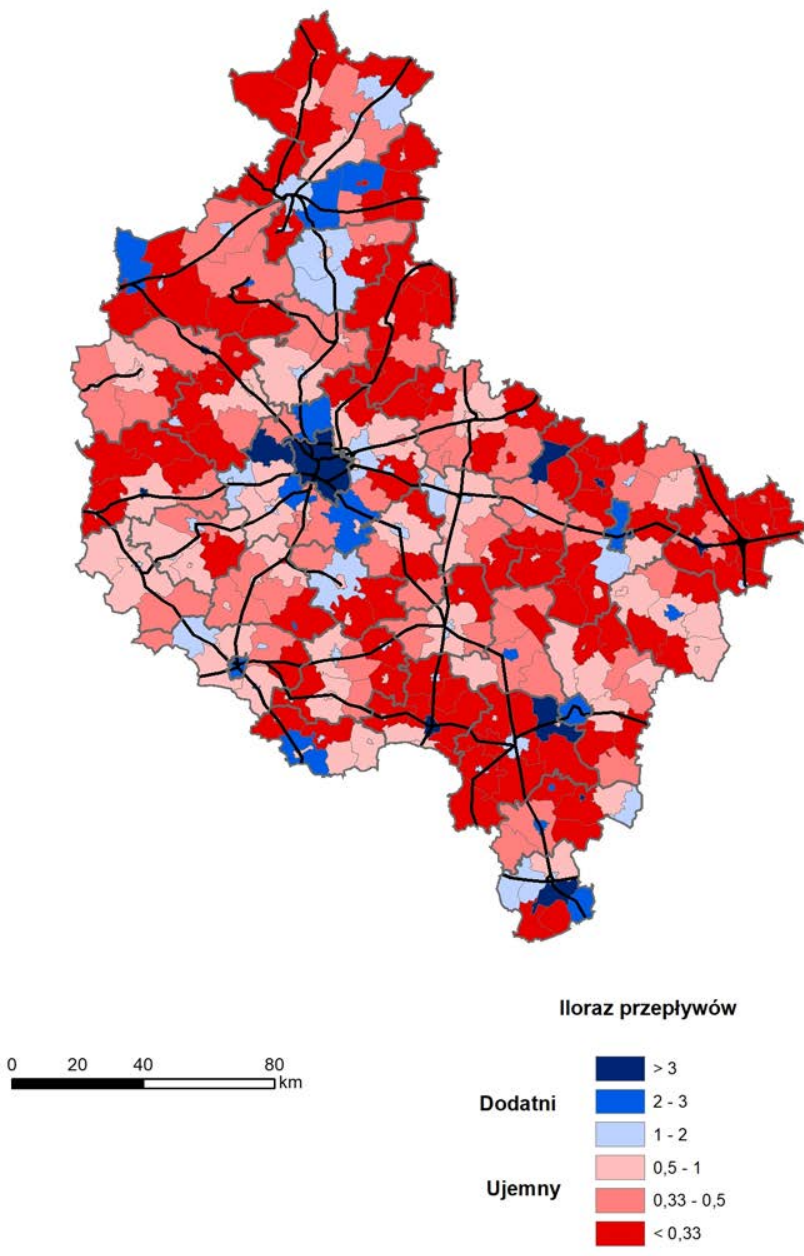

Ryc. 8. Iloraz przepływów pracowniczych w gminach województwa wielkopolskiego.

Źródło: opracowanie własne na podstawie danych GUS, 2019.

nostek i obejmuje gminy z powiatu szamotulskiego, międzychodzkiego, obornickiego i nowotomyskiego.

Podobnie jak w przypadku danych z roku 2011 można zauważyć, że niektóre z relacji łączących gminy regionu $z$ jednostkami podmiejskimi są niekiedy silniejsze aniżeli relacje $z$ miastem centralnym aglomeracji. Poza dojazdami do Poznania warto zwrócić m.in. uwagę na przemieszczenia z Szamotuł, Dusznik czy Kaźmierza do Tarnowa Podgórnego (ryc. 9), ze Stęszewa i Kościana do Komornik (ryc. 10) oraz ze Śremu i Środy Wielkopolskiej do gminy Kórnik (ryc. 11). Należy zatem podkreślić, że istotne znaczenie z punktu widzenia funkcjonowania aglomeracyjnego rynku pracy mają nie tylko przemieszczenia do miasta centralnego, ale także do niektórych jednostek gminnych (Bul, 2015).

Warto również podkreślić, że podobnie jak w 2011 r. dane potwierdzają, iż rynek pracy w aglomeracji jest stosunkowo domknięty, a mieszkańcy gmin tworzących powiat poznański pracują przede wszystkim na 


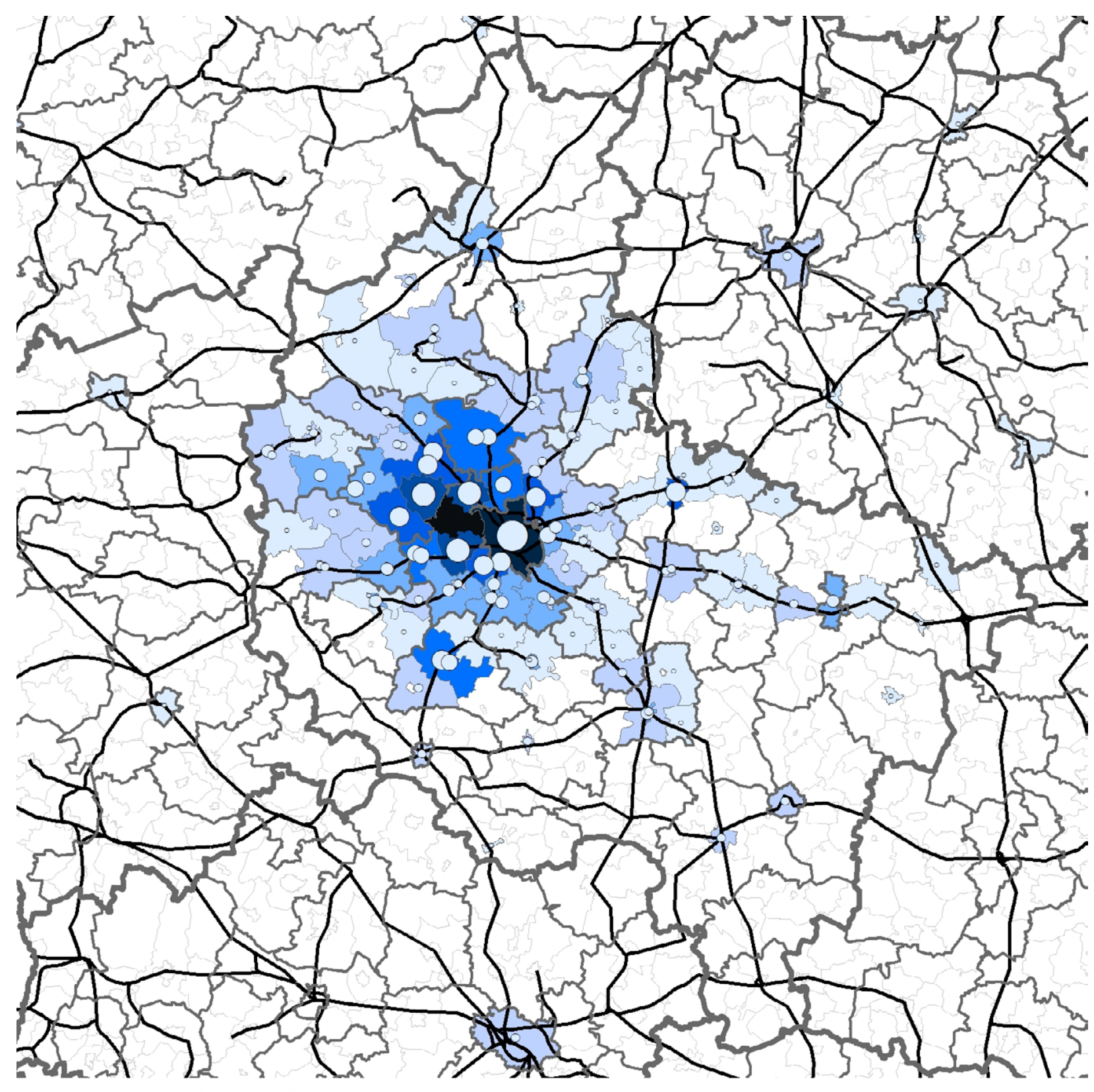

Liczba osób przyjeżdżających

$$
\begin{aligned}
& >2000 \\
& 1000-2000 \\
& \quad 500-1000 \\
& \quad 200-500 \\
& \quad 100-200 \\
& \quad 50-100 \\
& 20-50 \\
& 10-20 \\
& <10
\end{aligned}
$$

Liczba osób przyjeżdżających

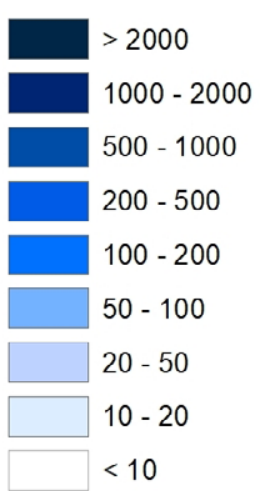

40

Ryc. 9. Przyjazdy do pracy do Tarnowa Podgórnego.

Źródło: opracowanie własne na podstawie danych GUS, 2019. 


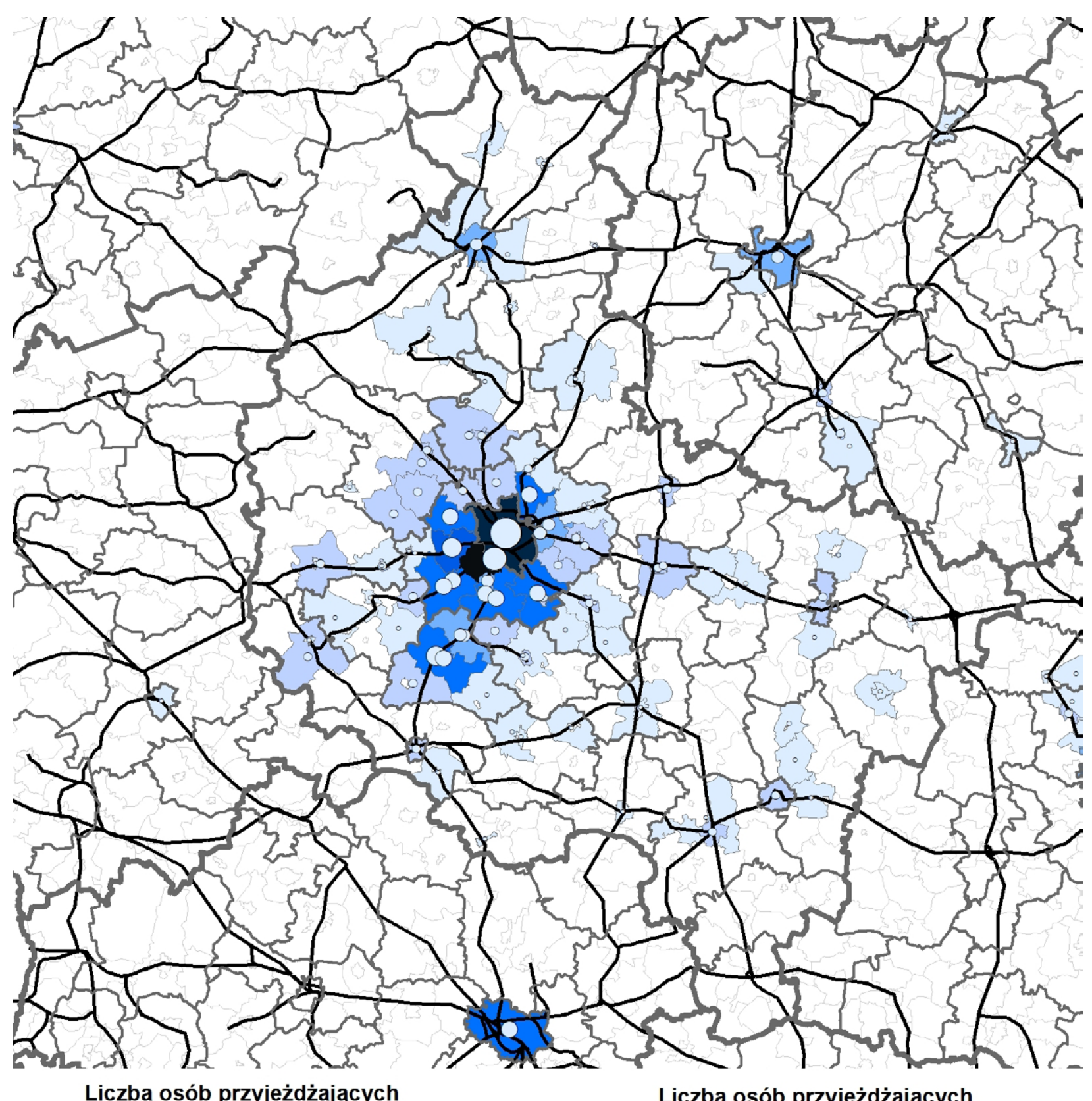

$$
\begin{aligned}
& \text { > }>2000 \\
& 1000-2000 \\
& \bigcirc \quad 500-1000 \\
& \bigcirc \quad 200-500 \\
& 0 \quad 100-200 \\
& \quad 50-100 \\
& \quad 20-50 \\
& \quad 10-20 \\
& <10
\end{aligned}
$$

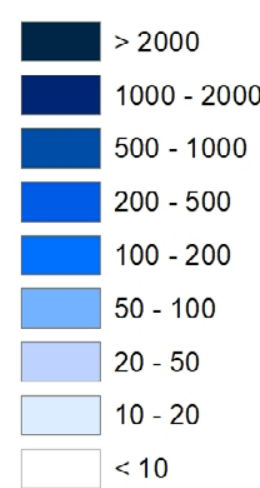




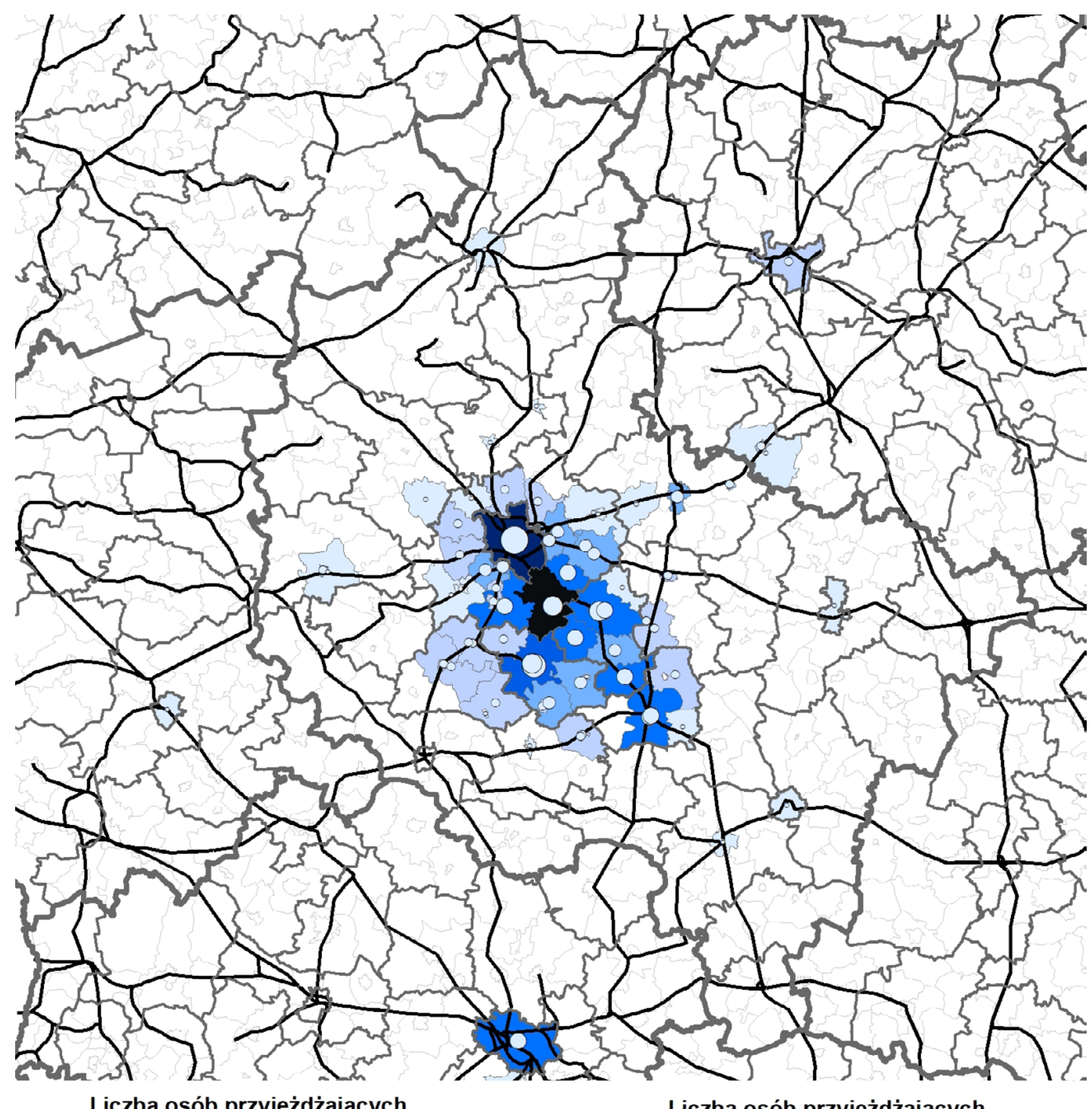

Liczba osób przyjeżdżających

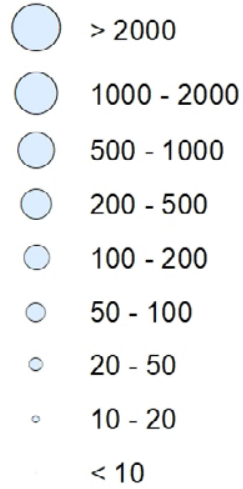

Liczba osób przyjeżdżających

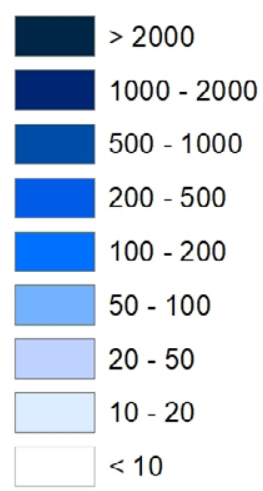

80

Ryc. 11. Przyjazdy do pracy do Kórnika - obszaru wiejskiego.

Źródło: opracowanie własne na podstawie danych GUS, 2019. 
obszarze powiatu ziemskiego i Poznania (cele dojazdów w 95\%). Tylko niewielki odsetek mieszkających w powiecie dojeżdża poza aglomerację. Dominują tu wyjazdy do powiatów graniczących z powiatem poznańskim oraz do Warszawy (2,5 tys. osób, tj. 4\%).

Analogiczna metodologia pozyskiwania danych przez GUS dla roku 2011 i 2016 pozwoliła na zaprezentowanie zjawiska w ujęciu dynamicznym (tab. 6, ryc. 12-13). Dane wskazują jednoznacznie na wzrost znaczenia jednostek podmiejskich, jako ośrodków dojazdów kosztem przemieszczeń do głównego miasta aglomeracji. Zmniejszenie liczby osób dojeżdżających do Poznania odnotowano w przypadku kilku gmin wchodzących w skład aglomeracji, m.in. Swarzędza - miasta i Czerwonaka. Szczególnie wyraźne spadki dotyczą ośrodków subregionalnych, takich jak Piła, Ostrów Wlkp., Kalisz i Leszno. Wyraźnie dostrzegalny jest także ubytek liczby dojeżdżających $z$ innych dużych ośrodków miejskich w kraju, takich jak: Kraków, Łódź, Bydgoszcz i Szczecin. Największe potoki wyjazdów do Poznania charakteryzowały przede wszystkim gminy podmiejskie, takie jak: Ko- morniki, Swarzędz - obszar wiejski, Dopiewo, Kórnik, Rokietnica, Kleszczewo, Mosina i Kostrzyn. Przyrosty odnotowano również w przypadku większości jednostek dobrze skomunikowanych z Poznaniem, głównie dzięki infrastrukturze kolejowej (choć zdarzały się wyjątki, w tym miasta subregionalne - Gniezno, Konin, Kalisz, Ostrów Wlkp., Leszno, Piła).

Można zaobserwować też znaczny wzrost liczby przemieszczeń do drugiego ośrodka dojazdów w regionie, tj. Tarnowa Podgórnego. W przypadku zdecydowanej liczby jednostek tworzących strefę oddziaływania tej gminy skala przemieszczeń pracowniczych wzrosła. Szczególnie intensywny wzrost odnotowano z jednostek bezpośrednio z nią graniczących, tj. Poznania, Dopiewa, Komornik, Rokietnicy, Kaźmierza i Dusznik. Większa liczba osób dojeżdżała w roku 2016 także z ośrodków subregionalnych, takich jak Kalisz, Gniezno czy Piła. Z kolei spadki liczby osób dojeżdżających do Tarnowa Podgórnego dotyczą zasadniczo jednostek zlokalizowanych w większej odległości od gminy, tj. Śremu, Kostrzyna, Swarzędza, Granowa, Lwówka czy Pniew.

Tab. 6. Zmiana liczby osób dojeżdżających do Poznania.

\begin{tabular}{|r|l|r|r|l|r|}
\hline \multicolumn{1}{|c|}{ Lp. } & \multicolumn{1}{|c|}{$\begin{array}{c}\text { Jednostka miejsca } \\
\text { zamieszkania }\end{array}$} & $\begin{array}{c}\text { Wzrost liczby osób } \\
\text { wyjeżdżających }\end{array}$ & \multicolumn{1}{|c|}{ Lp. } & \multicolumn{1}{|c|}{$\begin{array}{c}\text { Jednostka miejsca } \\
\text { zamieszkania }\end{array}$} & $\begin{array}{c}\text { Wzrost liczby osób } \\
\text { wyjeżdżających }\end{array}$ \\
\hline 1 & Komorniki & 476 & 1 & Piła & -743 \\
\hline 2 & Swarzędz - obszar wiejski & 433 & 3 & Kraków & -467 \\
\hline 3 & Dopiewo & 342 & 4 & Ostrów Wielkopolski & -419 \\
\hline 4 & Kórnik - obszar wiejski & 233 & 5 & Czerwonak & -364 \\
\hline 5 & Rokietnica & 195 & 6 & Kalisz & -360 \\
\hline 6 & Kleszczewo & 175 & 7 & tódź & -345 \\
\hline 7 & Mosina - obszar wiejski & 165 & 8 & Bydgoszcz & -253 \\
\hline 8 & Kobylin - miasto & 155 & 9 & Szczecin & -230 \\
\hline 9 & Pępowo & 134 & 10 & Leszno & -223 \\
\hline 10 & Kostrzyn - obszar wiejski & & & \\
\hline
\end{tabular}

Źródło: opracowanie własne na podstawie danych GUS, 2019. 


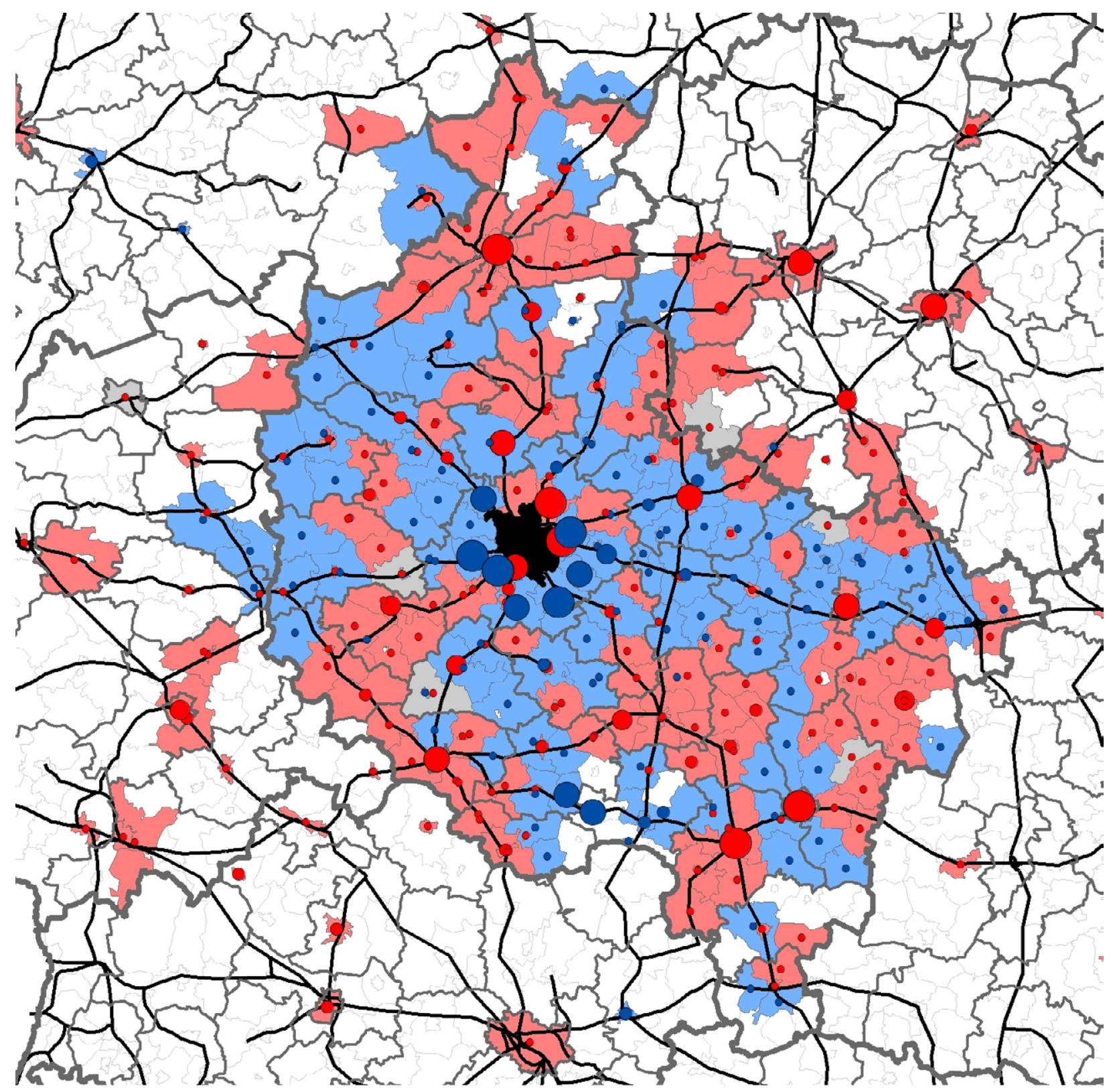

Zmiana liczby osób przyjeżdżających

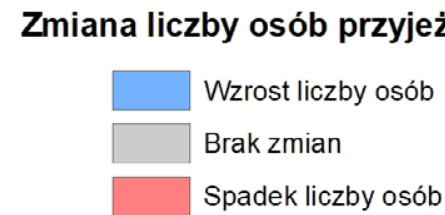

0

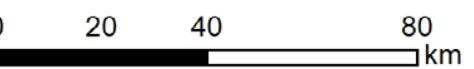

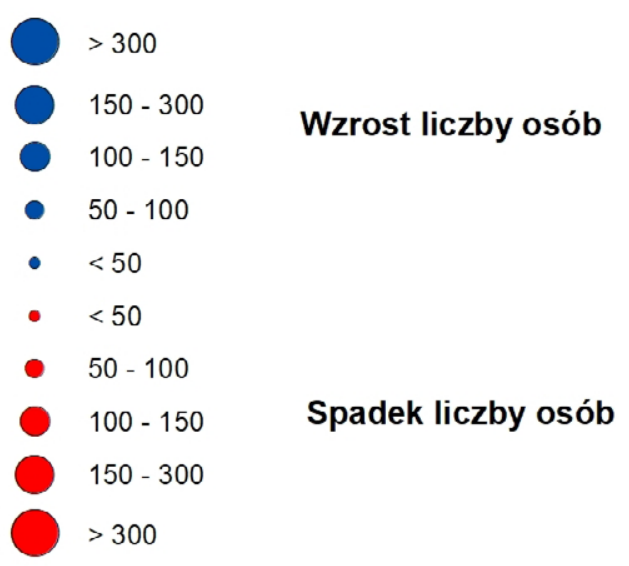

Ryc. 12. Zmiana liczby osób dojeżdżających do Poznania.

Źródło: opracowanie własne na podstawie danych GUS, 2019. 


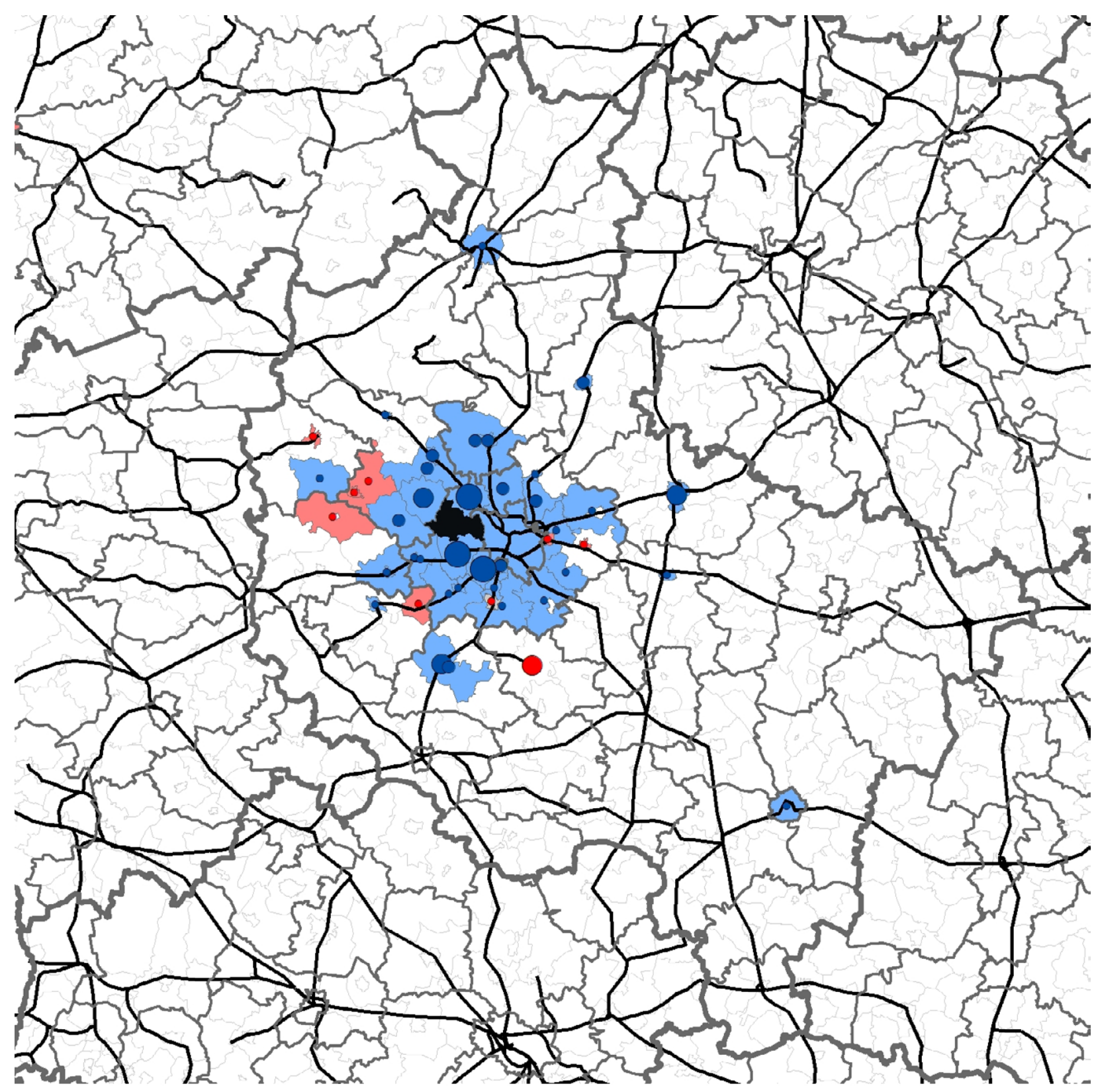

Zmiana liczby osób przyjeżdżających

Zmiana liczby osób przyjeżdżających
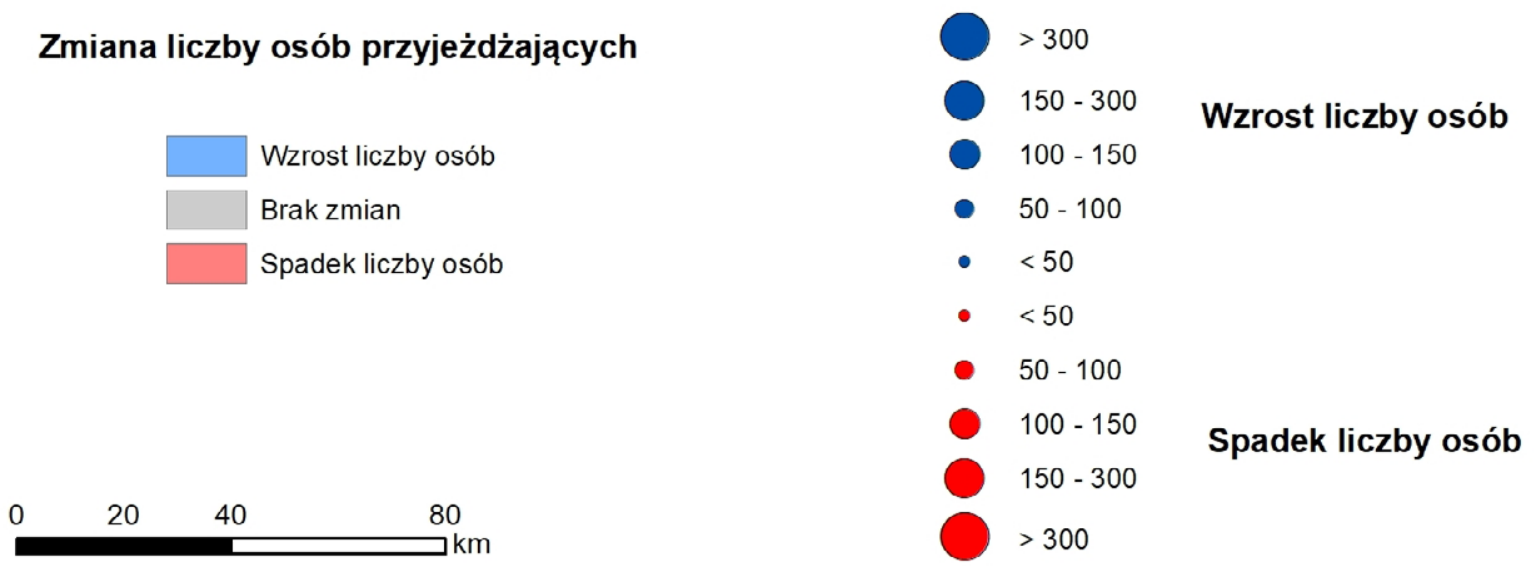

Ryc. 13. Zmiana liczby osób dojeżdżających do Tarnowa Podgórnego.

Źródło: opracowanie własne na podstawie danych GUS, 2019. 


\section{Podsumowanie}

Zaprezentowane analizy potwierdzają po raz kolejny znaczenie jednostek wchodzących w skład województwa wielkopolskiego jako dużych ośrodków pracy, czego identyfikatorem są przemieszczenia pracowników. Ponadto informacje statystyczne wskazują ma istnienie silnych relacji przestrzennych pomiędzy jednostkami gminnymi jakie zachodzą w szczególności na obszarach zurbanizowanych, w tym głównie w aglomeracji poznańskiej. Dane opublikowane przez GUS dla roku 2011 i 2016 ukazują jednocześnie zmiany w strukturze dojazdów, zarówno jeśli chodzi o ich skalę, jak i kierunki. Z uwagi na przekształcenia w ramach systemów transportowych i rynków pracy oraz zmiany zachowań migracyjnych mieszkańców, wielkość przemieszczeń do poszczególnych jednostek zmienia się w ostatnich latach coraz dynamiczniej.

Potwierdzono też istnienie na obszarze aglomeracji poznańskiej znaczącego (prawdopodobnie trzeciego co do wielkości w kraju) rynku pracy. Dane z roku 2016, podobnie jak te z roku 2011 wskazują, że jest to rynek o wybitnie aglomeracyjnym charakterze, tj. składa się na niego zarówno potencjał gospodarczy miasta Poznania, jak i gmin tworzących powiat poznański. Z uwagi na coraz mniejsze zróżnicowanie funkcjonalne miasta centralnego i gmin wchodzących w obrębie jego strefy podmiejskiej występują coraz silniejsze powiązania pomiędzy jednostkami. Efektem lokalizacji rosnącej liczby miejsc pracy w gminach jest wzrost skali przemieszczeń związanych w wykonywaniem działalności zarobkowej (Bul, 2015).

Największym ośrodkiem dojazdów w regionie i aglomeracji jest miasto Poznań, które stanowi również trzecie największe centrum dojazdów w Polsce. Dane GUS uwidaczniają istotne przepływy w tym kierunku z jednostek położonych w niemalże całym województwie wielkopolskim. Szczególnie silne powiązania zaobserwowano $w$ ramach samej aglomeracji i na obszarze do $70 \mathrm{~km}$ od miasta centralnego. Obok niego funkcjonują mniejsze, aczkolwiek ważne w skali regionu, rynki pracy zlokalizowane w jednostkach powiatu poznańskiego i miastach subregionalnych. Na tym tle wyróżnia się przede wszystkim gmina Tarnowo Podgórne, która stanowi 19. w skali kraju i drugi w regionie ośrodek migracji pracowniczych. Wyniki badań potwierdzają również, że na obszarze samej aglomeracji funkcjonuje stosunkowo domknięty rynek pracy. Przyciąga ona pracowników obszaru całego województwa, natomiast wyjazdy mieszkańców gmin podpoznańskich ograniczają się w zasadzie do obszaru Poznania i gmin powiatu ziemskiego.
Niewątpliwie na skalę przemieszczeń pracowniczych wpływ ma stopa bezrobocia rejestrowanego w poszczególnych gminach. Zgodnie z danymi GUS województwo wielkopolskie jest regionem o najniższej stopie bezrobocia w kraju, co niewątpliwie wpływa na redukcję skali przemieszczeń w roku 2016 w porównaniu z rokiem 2011 (szczególnie dotyczy to kierunku do Poznania z ośrodków subregionalnych). Warto w tym miejscu podkreślić pozytywne skutki dojazdów w zakresie łagodzenia nierównomiernego rozkładu przestrzennego miejsc pracy. Ponadto, jak wskazuje T. Lijewski (1967), duża mobilność mieszkańców jest dowodem na ich elastyczność i umiejętność dostosowania się do wielu sytuacji życiowych. Dojazdy do pracy w Polsce są także formą przezwyciężania trudności mieszkaniowych.

Wyniki badań pozwalają na przypuszczenie, że w Polsce w najbliższym czasie skala tego typu przemieszczeń nadal będzie rosnąć. Największy wzrost dotyczyć powinien gmin podmiejskich zlokalizowanych w dużych zespołach miejskich, takich jak aglomeracja poznańska. Proces stymulować będzie przede wszystkim rosnąca liczba mieszkańców aglomeracji, dalsza dekoncentracja rozmieszczenia ludności na ich obszarach oraz postępująca tzw. suburbanizacja gospodarcza, przejawiająca się powstawaniem dużej liczby miejsc pracy (przede wszystkim w sektorze przemysłowo-usługowym) na obszarach gmin podmiejskich.

\section{Piśmiennictwo}

Bul R., 2011, Dojazdy ludności do pracy w aglomeracji poznańskiej, Transport Miejski i Regionalny, 7/8, 31-39.

Bul R., 2012, Berufspendlerströme in der Posener Agglomeration, [w:] R. Wehrhahn, A. Toelle (red.), Aktuelle Entwicklungen in norddeutschen und westpolnischen Stadtregionen, Kieler Arbeitspapiere zur Landeskunde und Raumordnung, Christian-Albrechts-Universität zu Kiel, Kilonia, 109-122.

Bul R., 2014, Migracje wahadłowe mieszkańców aglomeracji poznańskiej, Biblioteka Aglomeracji Poznańskiej, 24, Bogucki Wydawnictwo Naukowe, Poznań.

Bul R., 2015, Dojazdy do pracy w aglomeracji poznańskiej w 2011 r., Rozwój Regionalny i Polityka Regionalna, 32, Bogucki Wydawnictwo Naukowe, Poznań.

Churski P., Konecka-Szydłowska B., Perdał R., 2009, Rola aglomeracji miejskiej Poznania w kształtowaniu spójności regionu wielkopolskiego, [w:] P. Churski (red.), Spójność i konkurencyjność regionu wielkopolskiego, Wyniki projektu badawczego zrealizowanego w ramach konkursu z dotacji Ministerstwa Rozwoju Regionalnego w zakresie wdrażania funduszy strukturalnych na poziomie Narodowej Strategii Spójności, wersja CD, 1-55. 
Dojazdy do pracy w województwie wielkopolskim w 2016 r., 2019, Główny Urząd Statystyczny, Warszawa.

Gocał T., Rakowski W., 1991, Delimitacja regionów i subregionów migracyjnych w zakresie dojazdów do pracy, Monografie i Opracowania, 332, Szkoła Główna Planowania i Statystyki, Warszawa.

Gruchociak H., 2013, Delimitacja lokalnych rynków pracy w Polsce z wykorzystaniem modelowania wielopoziomowego, Rozprawa doktorska w Katedrze Statystyki na Uniwersytecie Ekonomicznym w Poznaniu pod kierunkiem dr hab. Elżbiety Gołaty i dr. Tomasza Klimanka.

Jagielski A., 1974, Geografia ludności, Państwowe Wydawnictwo Naukowe, Warszawa.

Kaczmarek T., Mikuła Ł., 2007, Ustroje terytorialno-administracyjne obszarów metropolitalnych w Europie, Bogucki Wydawnictwo Naukowe, Poznań.

Kaczmarek U., Mikuła Ł., 2009, Mobilność siły roboczej na rynku pracy aglomeracji poznańskiej, [w:] P. Churski (red.), Rynek pracy i mobilność siły roboczej w aglomeracji poznańskiej, Biblioteka Aglomeracji Poznańskiej, 5, Bogucki Wydawnictwo Naukowe, Poznań.

Kitowski J., 1988, Rola dojazdów do pracy w gospodarce narodowej, Rozprawy Wydziału Ekonomicznego, Rozprawy Habilitacyjne, XIV, Uniwersytet Marii Curie-Skłodowskiej, Lublin.

Klebba E., 1995, Wpływ dojazdów do pracy na kształtowanie się poziomu życia ludności wsi województwa poznańskiego, Prace Komisji Geograficzno-Geologicznej, 23, Wydawnictwo Poznańskiego Towarzystwa Przyjaciół Nauk, Poznań.

Korcelli P., 1976, Aglomeracje miejskie w systemach osadniczych, Przegląd Geograficzny, 48(4), 589-599.

Lijewski T., 1967, Dojazdy do pracy w Polsce, Studia KPZK PAN, 15, Komitet Przestrzennego Zagospodarowania Kraju, Warszawa.

Pacione M., 2001, Urban Geography, Routledge, Londyn. Potrykowska A., 1995, Regiony dojazdów do pracy 1983, Atlas Rzeczypospolitej Polskiej, plansza 65.4, mapa 1, Główny Geodeta Kraju, Warszawa.

Przepływy ludności zwiq̨zane z zatrudnieniem w 2016 r., 2019, Główny Urząd Statystyczny (https://stat.gov.pl/obszary-tematyczne/rynek-pracy/opracowania/przeplywy-ludnosci-zwiazane-z-zatrudnieniem-w-2016-r-,20,1. html).

Runge J., 1991, Dojazdy do pracy w przestrzennej strukturze powiązań miast województwa katowickiego, Prace Naukowe Uniwersytetu Śląskiego w Katowicach, 1198.

Śleszyński P., 2012, Kierunki dojazdów do pracy, Wiadomości Statystyczne, 11, 59-75.

Wiśniewski R., 2013, Społeczno-demograficzne uwarunkowania dojazdów do pracy do Białegostoku, Prace Geograficzne, 244, IGiPZ PAN, Warszawa. 